\title{
Circular economy approach for rice husk modification: Equilibrium, kinetic, thermodynamic aspects and mechanism of Congo red adsorption
}

\section{Nina Mladenovic}

Ss Cyril and Methodius University in Skopje Faculty of Technology and Metallurgy: Saints Cyril and Methodius University in Skopje Faculty of Technology and Metallurgy

\section{Jovana Petkovska}

Ss Cyril and Methodius University in Skopje Faculty of Technology and Metallurgy: Saints Cyril and Methodius University in Skopje Faculty of Technology and Metallurgy

\section{Vesna Dimova}

Ss Cyril and Methodius University in Skopje Faculty of Technology and Metallurgy: Saints Cyril and Methodius University in Skopje Faculty of Technology and Metallurgy

\section{Dejan Dimitrovski}

Ss Cyril and Methodius University in Skopje Faculty of Technology and Metallurgy: Saints Cyril and Methodius University in Skopje Faculty of Technology and Metallurgy

Igor Jordanov ( $\sim$ jordanov@tmf.ukim.edu.mk)

Faculty of Technology and Metallurgy, Ss. Cyril and Methodiius University https://orcid.org/0000-00029409-8197

\section{Research Article}

Keywords: dye removal, modification, rice husk, circular economy, adsorption

Posted Date: September 24th, 2021

DOl: https://doi.org/10.21203/rs.3.rs-899831/v1

License: (c) (7) This work is licensed under a Creative Commons Attribution 4.0 International License. Read Full License

Version of Record: A version of this preprint was published at Cellulose on November 19th, 2021. See the published version at https://doi.org/10.1007/s10570-021-04312-9. 


\section{8}

9

Circular economy approach for rice husk modification:

\author{
Equilibrium, kinetic, thermodynamic aspects and
}

\title{
mechanism of Congo red adsorption
}

Nina Mladenovic, Jovana Petkovska, Vesna Dimova, Dejan Dimitrovski, Igor Jordanov

Nina Mladenovic

Faculty of Technology and Metallurgy, Ss. Cyril and Methodius University in Skopje, Ruger

Boskovic 16, 1000 Skopje, Republic of North Macedonia

Jovana Petkovska

Faculty of Technology and Metallurgy, Ss. Cyril and Methodius University in Skopje, Ruger

Boskovic 16, 1000 Skopje, Republic of North Macedonia

Vesna Dimova

Faculty of Technology and Metallurgy, Ss. Cyril and Methodius University in Skopje, Ruger

Boskovic 16, 1000 Skopje, Republic of North Macedonia

Dejan Dimitrovski

Faculty of Technology and Metallurgy, Ss. Cyril and Methodius University in Skopje, Ruger

Boskovic 16, 1000 Skopje, Republic of North Macedonia 
Igor Jordanov

21 Faculty of Technology and Metallurgy, Ss. Cyril and Methodius University in Skopje, Ruger

22 Boskovic 16, 1000 Skopje, Republic of North Macedonia

$23+38975223534$

$24 \quad$ jordanov@tmf.ukim.edu.mk

25 Corresponding author:

26 Igor Jordanov: jordanov@ @mf.ukim.edu.mk

27 ORCID 0000-0002-9409-8197

\section{Abstract}

31 Equilibrium, kinetic, thermodynamic aspects and mechanism of Congo red adsorption onto rice

32 husk treated with effluent from cotton pre-treatment are examined by altering the initial dye

33 concentration, contact time, temperature, and adsorbent mass. When a lower mass is applied, the

34 treated rice husk adsorbs the Congo red following the Langmuir model, while at a higher mass,

35 the adsorption follows the Freundlich model. A maximum of $149.1 \mathrm{mg} / \mathrm{g}$ Congo red is adsorbed

36 with $10 \mathrm{~g} / \mathrm{L}$ rice husk at $70^{\circ} \mathrm{C}$. This capacity of the chemically modified rice husk is one of the

37 better ones found in the literature. The calculated Dubinin-Radushkevich activation energy

38 indicates the physical nature of Congo red adsorption adsorbed under the pseudo-second-order

39 kinetic model. The thermodynamic analysis confirmed spontaneous and endothermic adsorption

40 with physically created Congo red-rice husk bonds. These results showed the applicability of the

41 circular economy concept in the effort to obtain an efficient adsorbent without wasting additional 
42 chemicals and energy that could be used to create a continuous column-mode process of rice

43 husk modification and purification of colored effluent from the textile industry.

44

\section{Graphical abstract}

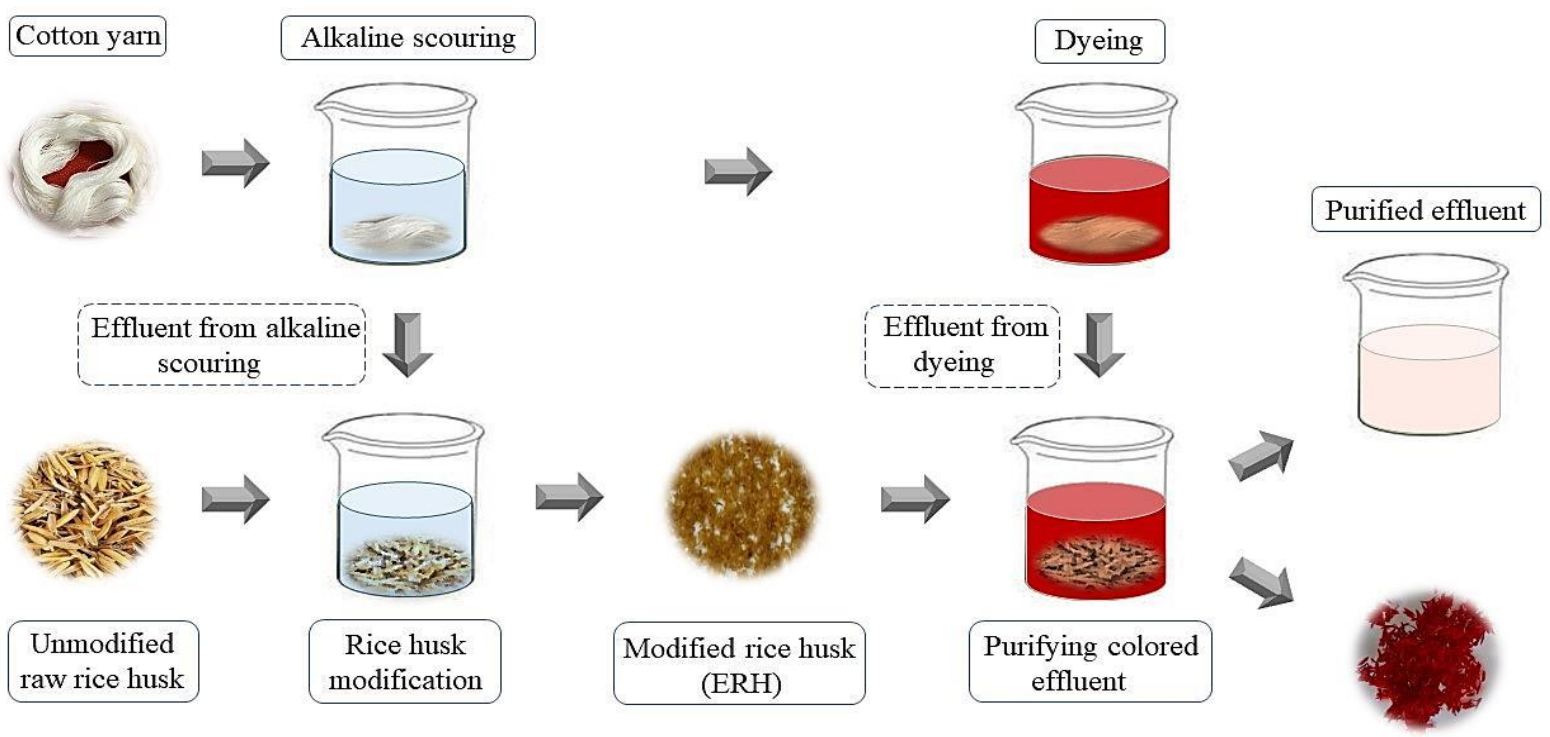

Modified rice husk adsorption capacity up

Key words: dye removal, modification, rice husk, circular economy, adsorption

- Treatment of rice husk with effluent from cotton pretreatment.

- Equilibrium, kinetic, thermodynamic and mechanism of adsorption are tested.

- $\quad 149.1 \mathrm{mg} / \mathrm{g}$ adsorption capacity of treated rice husk.

- The adsorption is physical, spontaneous and endothermic. 
55 Direct (substantive) dyes are water-soluble colorants for dyeing cellulosic fabrics when good

56 lightfastness is required, but washing-fastness is not crucial (Broadbend 2001). As sulfonated azo

57 chemicals, they are serious pollutants (Blackburn 2004), because their degradation products are

58 highly carcinogenic (Brown and De Vito 1993). Effluent from dyeing of cellulosic fibers, with 5-

$5930 \%$ residual direct dye (Easton 1995) has a negative environmental impact and a toxic influence

60 on aquatic organisms because of its high biochemical oxygen demand that results in the

61 suffocation of aquatic flora and fauna. Several studies for cleaning the colored effluent have been

62 examined. Biological treatment using activated sludge (Abu Elella et al. 2019), chemical

63 treatment with oxidation (Alaton and Teksoy 2007) and ozonation (Ciardelli et al. 2001) and

64 physical methods by implementing membrane technology (Males et al. 2020; Gorgieva et al.

65 2019), ion-exchange materials (Shao X et al. 2021), polyelectrolytes (Qiao et al. 2021),

66 biomasses (Halysh et al. 2020), nanostructures (Batmaz et al. 2014; Aboamera et al. 2018),

67 cellulose-based hydrogels (Ching et al. 2018; Mohamed et al. 2018) cellulose-based aerogels

68 (Chong et al. 2015) and biopolymers (Perez-Ameneiro et al. 2014) have been explored. Many of

69 these treatments are expensive and have limited effectiveness that requires additional extensive

70 examination. Adsorption of dye molecules is one of the cheapest methods for purifying colored

71 effluent from the textile industry based on employing cheap and highly effective adsorbents.

72 Many adsorbents show effective dye absorbency, but most of them are either expensive or have

73 limited absorptivity. One of the commercially available adsorbents, which possess excellent

74 adsorption ability, is activated carbon (Foo and Hameed 2010). Despite its high efficiency, its

75 expensive fabrication limits its use as a dyed effluent purifier (Abdelwahab et al. 2005). 
The latest development in colored effluent cleaning is related to using an agricultural byproduct,

77 or industrial waste, as an adsorbent, that is inexpensive and abundant. Grass waste, leaf, fly ash,

78 sugarcane bagasse, sludge ash, wheat straw, natural fibers, rice husk, etc., have been tested as

79 potential adsorbents (Chakraborty et al. 2011; Gupta et al. 2009; Sanghi and Verma 2013;

80 Sharma et al. 2011; Tarbuk et al. 2020; Toshikj et al. 2019). Some of them are highly efficient,

81 but many require additional modification steps to make them more amenable for dye sorption.

82 Rice husk with its chemical composition containing $32 \%$ cellulose, $21 \%$ hemicellulose, $21 \%$

83 lignin, 20\% silica, 3\% crude proteins (Chowdhury et al. 2011), which is similar to the

84 composition of natural cellulose fibers (Ivanovska et al. 2019; Lazic et al. 2018), emphasizes its

85 use as a purifier for colored effluent (Chakraborty et al. 2011; Mladenovic et al. 2020;

86 Shamsollahi and Partovinia 2019). Despite the theoretically good ability for dye adsorption, the

87 content of $21 \%$ lignin in its outer protective layer i.e. the hydrophobic lignin-silicone-cellulose

88 shield, makes the rice husk less adsorptive (Ndazi et al. 2007). In order to improve its adsorption

89 capacity, the rice husk was subjected to physical grounding (Vadivelan \& Kumar 2005),

90 incineration (Alam et al. 2020), chemical treatments with acids (Abdelwahab et al. 2005),

91 ethylenediamine (Ong et al. 2007) and bases (Chowdhury et al. 2011; Chowdhury et al. 2012).

92 These modifications are effective but require an investment in expensive equipment that operates

93 at high temperatures under pressure.

94 Alkaline scouring of cotton is a process that uses dilute sodium hydroxide solution and 95 surfactants to remove non-cellulosic hydrophobic components from cotton's cuticle and to make 96 it hydrophilic (Toshikj et al. 2016; Toshikj et al. 2017; Lazic et al. 2018). The circular economy

97 is a new concept opposite to the linear economy one, which is based on production, use, and 98 throwing away of the products. It is mainly focused on using the products and materials over and 
over, in a continuous loop. In this system, products and wastes are either reused or recycled. The

100 applicability of the circular economy concept for rice husk modification has been proved in

101 previous research (Mladenovic et al. 2020). In that study, rice husk was treated with cotton

102 scouring effluent as an inexpensive way of successful modification by avoiding the need for

103 additional energy and chemicals. Attenuated total reflectance-infrared spectroscopy (ATR-IR)

104 and scanning electron microscopy-energy dispersive X-ray (SEM-EDX) was used to observe the

105 occurred changes after this modification. The results of these analyzes showed that the treatment

106 with effluent from alkaline scouring effectively removed the lignin-silicone shield from the rice

107 husk surface. Moreover, this treatment increased the percentage of cellulose in the husk and the

108 structure became cellulose-dominant and more amenable for purifying the colored effluent.

109 The present study explored equilibrium, kinetics, thermodynamics, and the adsorption 110 mechanism of Congo red (CR) onto rice husk modified with cotton scouring effluent (ERH), by 111 the concept of circular economy. The results show that this approach is effective in obtaining an 112 efficient adsorbent for dye removal. Moreover, such modified rice husk has an exceptional 113 absorption capacity higher than other chemically modified rice husks found in the literature.

115 2. Materials and methods

116 2.1. Materials

117 The collected rice husk was sifted through a sieve to eliminate tiny particles with a size less than $1181.25 \mathrm{~mm}$ and dried at $105^{\circ} \mathrm{C}$ for 2 h. Congo red dye - C.I. 20120 (Sigma-Aldrich, Milwaukee, 119 WI) was used as received. All experimental dye solutions with defined concentrations were 
120 prepared by diluting the stock solution which has $1 \mathrm{~g} / \mathrm{L}$ concentration. Sodium hydroxide and

121 sodium chloride were supplied by Sigma-Aldrich (Milwaukee, WI). Cotoblanc HTD-N (CHT

122 Switzerland AG), anionic washing surfactant and Kemonecer NI (Kemo Croatia), nonionic

123 wetting surfactant are used as received.

124

125

126

127

128

129

130

131

132

133

134

135

\subsection{Rice husk modification}

Rice husk was treated with effluent from cotton scouring. The effluent was obtained after cotton yarn scouring, done with a solution containing $25 \mathrm{~g} / \mathrm{L}$ of sodium hydroxide, $2 \mathrm{~mL} / \mathrm{L}$ Cotoblanc HTD-N and $1 \mathrm{~mL} / \mathrm{L}$ Kemonecer NI in a bath with 50:1 liquor ratio at $100^{\circ} \mathrm{C}$ for $60 \mathrm{~min}$ in Ahiba Turbomat TM-6 apparatus. Then, the collected effluent was mixed with the raw rice husk (with a ratio of effluent and husk 20:1) and treated for $30 \mathrm{~min}$ in the Linitest apparatus. During this treatment, the effluent temperature decreased from $100^{\circ} \mathrm{C}$ to $40^{\circ} \mathrm{C}$ with an average temperature of $70^{\circ} \mathrm{C}$. Then, the rice husk was rinsed with effluents from cotton yarn rinsing, performed at $70^{\circ} \mathrm{C}$ for $15 \mathrm{~min}$ (warm rinsing) and $25^{\circ} \mathrm{C}$ temperature for $15 \mathrm{~min}$ (cold rinsing).

\subsection{Adsorption studies}

The adsorption ability of treated rice husk is examined by employing a batch adsorption process where 2, 4, and $8 \mathrm{~g}$ rice husk (i.e. 10, 20, and $40 \mathrm{~g} / \mathrm{L}$ adsorbent dosage) are added in a $200 \mathrm{~mL}$ colored solution (in a glass stoppered Erlenmeyer flask) with an initial dye concentration of 0.1, 0.2, 0.3, 0.4, and 0.5 g/L Congo red, $10 \mathrm{~g} / \mathrm{L} \mathrm{NaCl}$ at $\mathrm{pH} 7$, at 298, 323, and $343 \mathrm{~K}$ with constant agitation of $60 \mathrm{~min}^{-1}$ in a GLF-shaking water bath 1083 (EURO lux GmbH \& Co. KG KarlstadtKarlberg, Germany). Pipetting of the dye solution was done at 10, 20, 30, 40, 60, 90, 120, 360, 
142720 , and $1440 \mathrm{~min}$ and the concentration of Congo red (max. wavelength at $507 \mathrm{~nm}$ ) in the 143 supernatant solution was measured with UV/VIS spectrophotometer (Model Hitachi - 2800, 144 United Kingdom). The calculated values are mean values of three measurements. The dye 145 removal efficiency, expressed as a percentage, was determined using Eq. 1.

$$
\text { Dye removal }(\%)=\left[\frac{\mathrm{C}_{0}-\mathrm{C}_{\mathrm{t}}}{\mathrm{C}_{0}}\right] * 100(\%)
$$

$147 \mathrm{C}_{0}(\mathrm{~g} / \mathrm{L})$ is the initial concentration of the dye and $\mathrm{C}_{\mathrm{t}}(\mathrm{g} / \mathrm{L})$ is the concentration of the dye after sorption at any time. The mass balance equation (Eq. 2) was used to calculate the amount of 149 adsorbed dye onto the rice husk $\mathrm{Q}_{\mathrm{e}}(\mathrm{g} / \mathrm{g})$.

150

$$
\mathrm{Qe}=\frac{\left(\mathrm{C}_{0}-\mathrm{C}_{\mathrm{e}}\right) * \mathrm{~V}}{\mathrm{~W}}
$$

$151 \mathrm{C}_{0}(\mathrm{~g} / \mathrm{L})$ and $\mathrm{Ce}(\mathrm{g} / \mathrm{L})$ are the initial concentration and the concentration of dye at equilibrium, 152 respectively, $\mathrm{V}(\mathrm{L})$ is the volume of the solution and $\mathrm{W}(\mathrm{g})$ is the weight of the sorbent used.

\section{Results and discussion}

155 The influence of adsorbent dosage, temperature, and initial dye concentration on the adsorption 156 ability of the sorbent has to be inter-correlated to obtain a clear picture of the sorption 157 phenomena for each sorbate-sorbent system. Hence, the adsorption ability of CR employing 158 three masses of ERH, five initial dye concentrations, and three temperatures is examined in this 159 study. The capability of the ERH to remove CR from solution with $0.3 \mathrm{~g} / \mathrm{L}$ initial dye 160 concentration at 298, 323, and $343 \mathrm{~K}$, tested with 10, 20, and $40 \mathrm{~g} / \mathrm{L}$ ERH are shown in Fig. 1 161 (a), (b) and (c), respectively. The increase in the ERH dosage and temperature of the dye solution 
162 increases the percent of removed dye. Increased ERH adsorbent dosage increases the specific 163 area and available adsorption sites, while higher temperatures make the dye molecules more 164 energy-active with a higher potential for adsorption onto the ERH surface. Opposite, a higher 165 initial dye concentration, at a constant adsorbent dosage and temperature of the solution, results 166 in a lower percentage of removed dye (Fig. 2). A constant adsorbent dosage has a defined 167 adsorption ability, so the percentage of removed dye decreases as the initial dye concentration 168 increases. The complete data of the dye removal versus contact time, conducted under all 169 combined parameters, are given as a supplementary file.

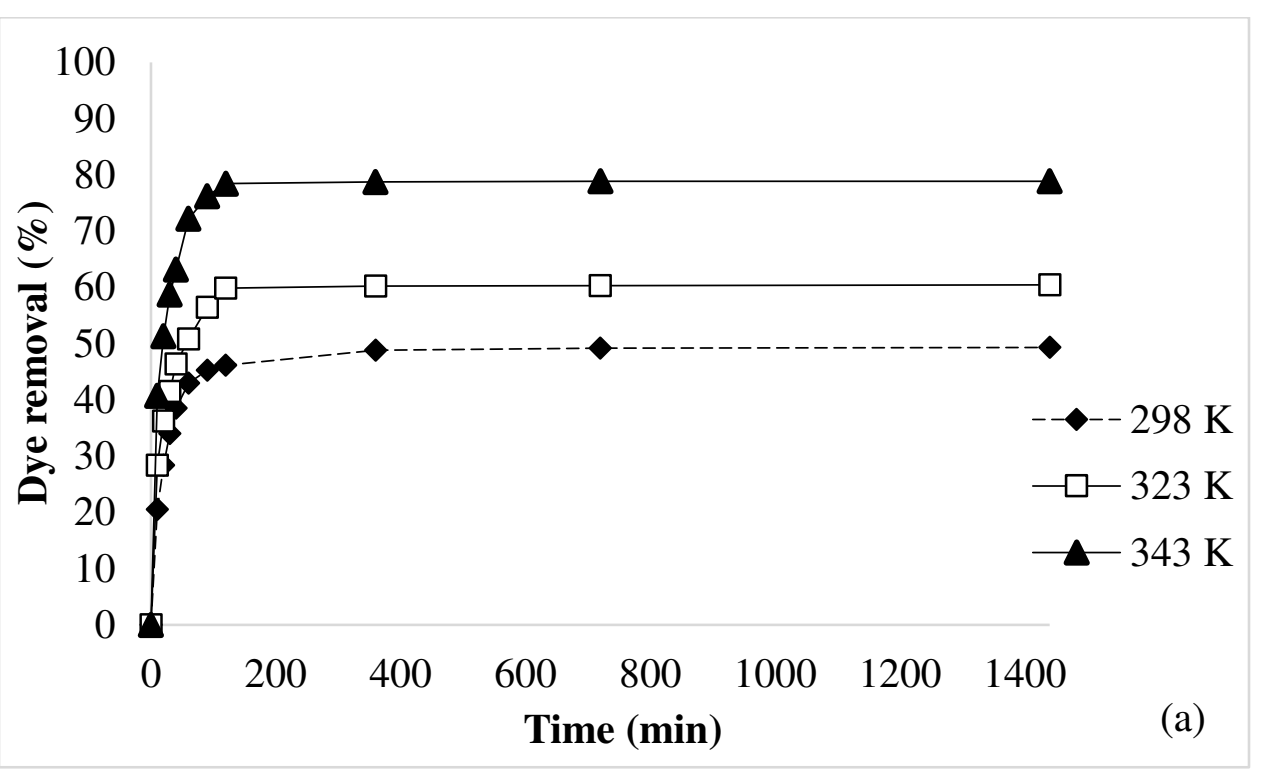




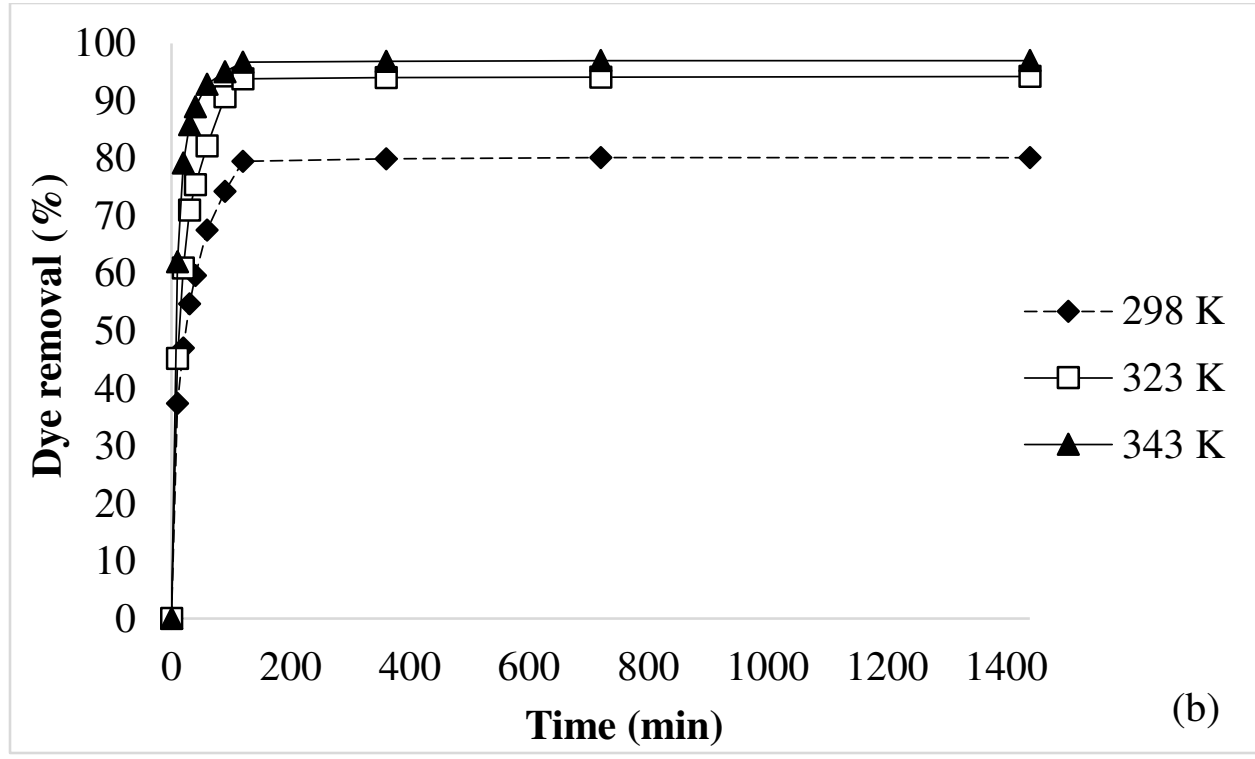

172

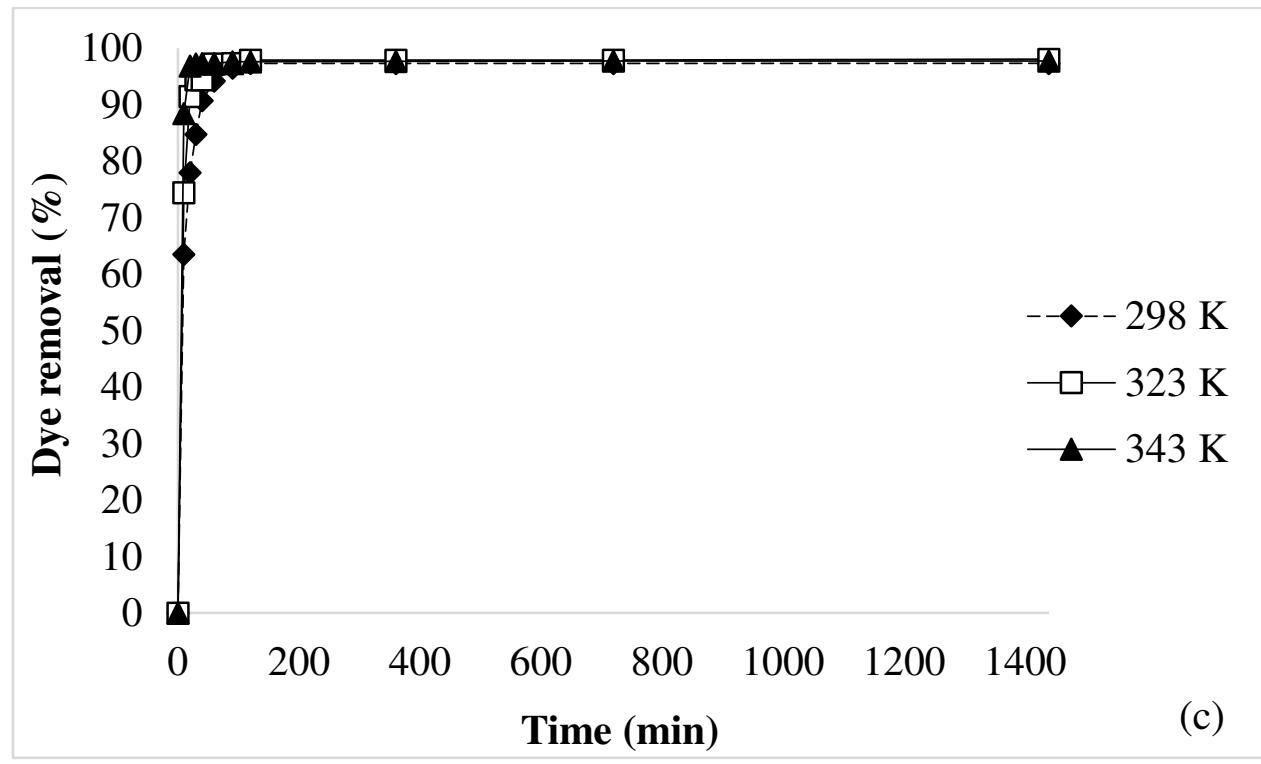

173 Fig. 1 Effect of ERH dosage on dye removal tested with 0.3 g/L CR at 298, 323 and 343 K. (a) $17410 \mathrm{~g} / \mathrm{L}$, (b) $20 \mathrm{~g} / \mathrm{L}$ and (c) $40 \mathrm{~g} / \mathrm{L}$ ERH dosage. 


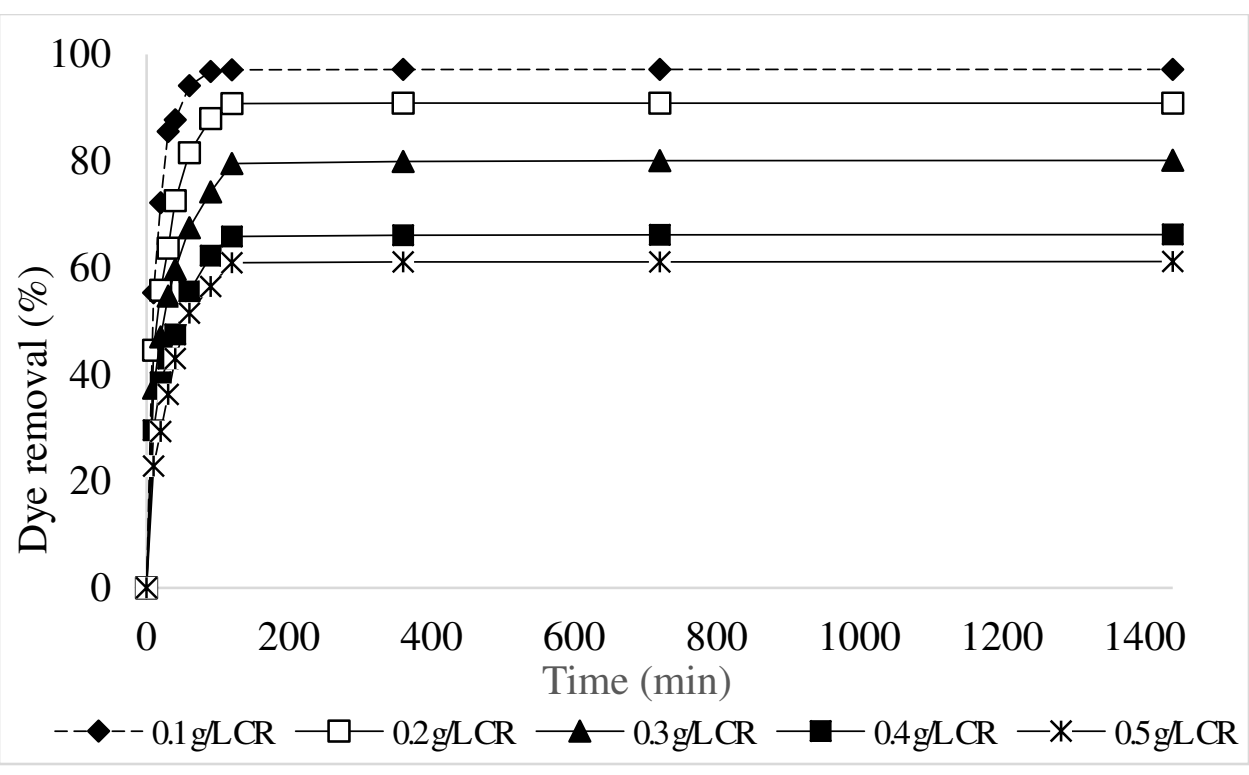

Fig. 2 Influence of initial dye concentration on CR removal tested with $20 \mathrm{~g} / \mathrm{L} \mathrm{ERH}$ at $298 \mathrm{~K}$.

179 In order to examine, explain and interpret the used adsorbent-adsorbate sorption system, the 180 adsorbent capacity must first be assessed. Langmuir and Freundlich's isotherms are the most 181 used equilibrium relationships between the adsorbate and adsorbent at a given sorption 182 condition. As such, they are essential for the evaluation of the physicochemical interaction 183 between $\mathrm{CR}$ and ERH and the dye adsorption equilibrium analysis. According to the Langmuir 184 theory, dye adsorption is achieved through certain functional groups in the adsorbent. During the 185 reaction, these groups are saturated forming a monolayer, which prevents further absorption of 186 the dye. Also, in the Langmuir equation (Eq. 3), the dye concentration in the adsorbent increases 187 with the dye concentration in the bath but to some extent, i.e. until all active centers of the 188 adsorbent are saturated with dye. This isotherm has a linear form, as expressed in Eq. 4. 


$$
Q e=\frac{Q_{m} K_{L} C_{e}}{1+K_{L} C_{e}}
$$

$$
\frac{C_{e}}{Q_{e}}=\frac{1}{K_{L} Q_{m}}+\frac{1}{Q_{m}} C_{e}
$$

$191 \mathrm{Ce}(\mathrm{g} / \mathrm{L})$ is the equilibrium concentration of Congo red, Qe $(\mathrm{g} / \mathrm{g})$ is the amount of CR adsorbed 192 per unit mass of adsorbent, Qm $(\mathrm{g} / \mathrm{g})$ is constant related to adsorption capacity and $\mathrm{K}_{\mathrm{L}}(\mathrm{L} / \mathrm{g})$ is 193 constant related to rate of adsorption. Qm is calculated from the slope of the straight line when $194 \mathrm{Ce} / \mathrm{Qe}$ is plotted against Ce.

195 The Freundlich equation presented in Eq. 5 explain sorption on a heterogeneous surface with 196 sites of varied affinities.

$$
Q_{e}=K_{F} C e^{1 / n_{F}}
$$

The logarithmic form of Freundlich is given by Eq. 6 .

$$
\log (Q e)=\log \left(K_{F}\right)+\frac{1}{n_{F}} \log (C e)
$$

200 Qe $(\mathrm{g} / \mathrm{g})$ is the equilibrium dye concentration, Ce $(\mathrm{g} / \mathrm{L})$ is the equilibrium dye concentration in 201 solution, $\mathrm{K}_{\mathrm{F}}(\mathrm{g} / \mathrm{g})(\mathrm{L} / \mathrm{g})^{1 / \mathrm{n}}$ is the constant related to adsorption capacity, and $\mathrm{n}_{\mathrm{F}}$ is the adsorption 202 isotherm constant. $\mathrm{K}_{\mathrm{F}}$ and $1 / \mathrm{n}_{\mathrm{F}}$ are calculated from the intercept and slope of the straight line of 203 the plot $\log (\mathrm{Qe})$ versus $\log (\mathrm{Ce})$, respectively.

204 The Dubinin-Radushkevich (D-R) isotherm, which rules out the homogenous surface or constant 205 sorption potential, is empirical model for the adsorption of the adsorbate to the volume filling of 206 micropores (Dabrowski 2001). This isotherm is very important for determining the adsorption 207 characteristics of most of the industrial adsorbents with a complex and well-developed porous 
208 structure, including pores of different shapes and sizes, but micropores play the most significant 209 role. The non-linear equations of Dubinin-Radushkevich isotherm can be illustrated as Eq. 7 and 2108 (Chen 2015).

$$
\begin{aligned}
& Q_{e}=Q_{s} \exp \left(-K_{D R} \varepsilon^{2}\right) \\
& \varepsilon=R T \ln \left(1+\frac{1}{C_{e}}\right)
\end{aligned}
$$

$213 \mathrm{Q}_{\mathrm{s}}(\mathrm{g} / \mathrm{g})$ is a constant related to adsorption capacity, $\mathrm{K}_{\mathrm{DR}}\left(\mathrm{mol}^{2} / \mathrm{KJ}^{2}\right)$ is a constant related to the 214 mean free energy of adsorption, $\mathcal{E}$ is Polanyi potential, $\mathrm{Ce}(\mathrm{g} / \mathrm{L})$ is the concentration at 215 equilibrium, $\mathrm{R}(\mathrm{J} / \mathrm{mol} \mathrm{K})$ is the gas constant, and $\mathrm{T}(\mathrm{K})$ is the absolute temperature.

216 The linear expression of Dubinin-Radushkevich isotherm model is shown in Eq. 9.

$$
\ln Q_{e}=\ln Q_{m}-\beta \varepsilon^{2}
$$

$218 \mathrm{Q}_{\mathrm{m}}(\mathrm{g} / \mathrm{g})$ is the maximum adsorption capacity and $\beta\left(\mathrm{mmol}^{2} / \mathrm{J}^{2}\right)$ is a coefficient related to the 219 mean free energy of adsorption. Qm and $\beta$ are calculated from the intercept and slope of the plot 220 between $\ln$ Qe and $\varepsilon^{2}$, respectively.

$221 \beta$ is used to calculate $\mathrm{E}(\mathrm{KJ} / \mathrm{mol})$, the mean free energy of adsorption per mole of the adsorbate, 222 when the adsorbate is transferred from infinity of the solution to the surface of the solid. The 223 relation between them is shown in Eq. 10 (El Haddad 2016).

$224=\frac{1}{\sqrt{2 \beta}}$

225 E ranged from 8 to $16 \mathrm{KJ} / \mathrm{mol}$ indicates proceeds of the sorption process via chemisorption. 226 Values of $\mathrm{E}<8 \mathrm{KJ} / \mathrm{mol}$ indicate a physical sorption process (El Haddad 2016). 
227 The experimental adsorption capacity of ERH, the calculated constants of Langmuir, Freundlich

228 and D-R, and the coefficients of correlation between calculated and experimental data are

229 presented in Table 1 . The highest adsorption capacity of $149.1 \mathrm{mg} / \mathrm{g}$ is achieved when the lowest 230 adsorbent dosage (10 g/L ERH) and the highest temperature of $343 \mathrm{~K}$ are applied. The dye 231 removal is directly proportional, while the adsorption capacity of the ERH, at all temperatures is 232 inversely proportional to the adsorbent dosage. Higher dosage reduces the amount of the 233 adsorbed dye per unit weight of the adsorbents. The experimental adsorption capacity of the 234 ERH, tested with 10 and $20 \mathrm{~g} / \mathrm{L}$ adsorbent dosage, increases by about $63 \%$ as the temperature of 235 the adsorption testing rises from 298 to $343 \mathrm{~K}$. The adsorption capacities tested with $40 \mathrm{~g} / \mathrm{L}$ ERH 236 are not that temperature-dependent and increase for about $5 \%$ when the temperature of 237 adsorption increases from 298 to $343 \mathrm{~K}$. The calculated coefficients of correlation presented in 238 Table 1 show that the equilibrium data for $10 \mathrm{~g} / \mathrm{L}$ ERH fits the Langmuir better than the 239 Freundlich isotherm at all tested temperatures, confirming a monolayer coverage of the Congo 240 Red onto ERH when a lower adsorption dosage is used. The adsorption capacity for $20 \mathrm{~g} / \mathrm{L}$ ERH 241 at 298 and $323 \mathrm{~K}$, fits the Langmuir isotherm, while the one at $343 \mathrm{~K}$ fits the Freundlich isotherm 242 model better. The Freundlich isotherm proved to be a better fit for the equilibrium data for 40 $243 \mathrm{~g} / \mathrm{L}$ ERH at all tested temperatures. A list of published data on adsorption capacities of 244 chemically modified rice husks (Table 2) and the adsorption capacity of Congo red adsorbed 245 onto different renewable adsorbents (Table 3) indicate that capacity of the treated rice husk 246 obtained in this study is one of the better found in the literature.

247 The Langmuir isotherm could be also used to determine the dimensionless equilibrium 248 separation parameter $\mathrm{R}_{\mathrm{L}}$ calculated by Eq. 11 (Omidi and Kakanejadifard 2018). 


$$
R_{L}=\frac{1}{1+K_{L} C_{0}}
$$

$250 \mathrm{~K}_{\mathrm{L}}(\mathrm{L} / \mathrm{g})$ is the Langmuir constant related to adsorption capacity, while Co $(\mathrm{g} / \mathrm{L})$ is the initial 251 concentration of the dye solution. When $\mathrm{R}_{\mathrm{L}}<1$, the adsorption is favorable, while for values of $252 \mathrm{R}_{\mathrm{L}}>1$, it is unfavorable.

253 The $\mathrm{D}-\mathrm{R}$ isotherm is employed to calculate the magnitude of $\mathrm{E}$ which indicates the type of 254 adsorption. As mentioned above, the value of $\mathrm{E}$ higher than $8 \mathrm{KJ} / \mathrm{mol}$ is an indicator of chemical 255 ion exchange, while E below $8 \mathrm{KJ} / \mathrm{mol}$ indicates physical sorption (Chakraborty et al. 2011). The 256 E values presented in Table 1 are lower than $8 \mathrm{KJ} / \mathrm{mol}$ in most cases, confirming the physical 257 sorption of the CR onto ERH.

Table 1 Isotherm parameters for adsorption of Congo red onto ERH

\begin{tabular}{|c|c|c|c|c|c|c|c|c|c|c|}
\hline \multirow{4}{*}{ Isotherm } & \multirow{4}{*}{ Parameters } & \multicolumn{9}{|c|}{ Temperature (K) } \\
\hline & & & 298 & & & 323 & & \multirow{2}{*}{\multicolumn{3}{|c|}{ Adsorbent dosage (g/L) }} \\
\hline & & \multicolumn{3}{|c|}{ Adsorbent dosage (g/L) } & \multicolumn{3}{|c|}{ Adsorbent dosage (g/L) } & & & \\
\hline & & 10 & 20 & 40 & 10 & 20 & 40 & 10 & 20 & 40 \\
\hline & $\mathrm{Q}_{\mathrm{m}, \exp (\mathrm{g} / \mathrm{g})}$ & 0.0917 & 0.0765 & 0.0579 & 0.1153 & 0.0992 & 0.0608 & 0.1491 & 0.1126 & 0.0610 \\
\hline \multirow{4}{*}{ Langmuir } & $\mathrm{Q}_{\mathrm{m}}(\mathrm{g} / \mathrm{g})$ & 0.0932 & 0.0759 & 0.0667 & 0.1099 & 0.1011 & 0.0849 & 0.1465 & 0.1264 & 0.0888 \\
\hline & $\mathrm{K}_{\mathrm{L}}(\mathrm{l} / \mathrm{g})$ & 0.440 & 0.659 & 0.719 & 1.1039 & 1.5695 & 1.0279 & 2.347 & 1.887 & 0.968 \\
\hline & $\mathrm{R}_{\mathrm{L}}\left(\mathrm{C}_{\mathrm{o}}=0.1 \mathrm{~g} / \mathrm{L}\right)$ & 0.9578 & 0.9382 & 0.9329 & 0.9006 & 0.8643 & 0.9068 & 0.8099 & 0.8413 & 0.9117 \\
\hline & $\mathrm{R}^{2}$ & 0.985 & 0.988 & 0.933 & 0.979 & 0.987 & 0.550 & 0.985 & 0.930 & 0.391 \\
\hline \multirow{3}{*}{ Freundlich } & $\mathrm{K}_{\mathrm{F}}(\mathrm{g} / \mathrm{g})(\mathrm{l} / \mathrm{g})^{1 / \mathrm{n}}$ & 0.365 & 0.365 & 0.873 & 0.354 & 0.615 & 1.081 & 0.470 & 0.906 & 2.662 \\
\hline & $\mathrm{n}_{\mathrm{F}}$ & 1.544 & 1.842 & 1.436 & 2.165 & 1.768 & 1.461 & 2.284 & 1.630 & 1.438 \\
\hline & $\mathrm{R}^{2}$ & 0.6656 & 0.738 & 0.976 & 0.638 & 0.896 & 0.989 & 0.778 & 0.971 & 0.983 \\
\hline \multirow{4}{*}{$\begin{array}{l}\text { Dubinin- } \\
\text { Radushkevi } \\
\text { ch }\end{array}$} & $\mathrm{Q}_{\mathrm{m}}(\mathrm{g} / \mathrm{g})$ & 0.205 & 0.181 & 0.464 & 0.211 & 0.315 & 0.785 & 0.268 & 0.517 & 0.863 \\
\hline & $\beta\left(\mathrm{mmol}^{2} / \mathrm{J}^{2}\right)$ & $\begin{array}{c}1.86 \times 1 \\
0^{-8}\end{array}$ & $\begin{array}{c}1.14 \times 1 \\
0^{-8}\end{array}$ & $\begin{array}{c}1.76 \times 1 \\
0^{-8}\end{array}$ & $\begin{array}{c}0.88 \times 1 \\
0^{-8}\end{array}$ & $\begin{array}{c}1.12 \times 1 \\
0^{-8}\end{array}$ & $\begin{array}{c}1.61 \times 1 \\
0^{-8}\end{array}$ & $\begin{array}{c}0.68 \times 1 \\
0^{-8}\end{array}$ & $\begin{array}{c}1.23 \times 1 \\
0^{-8}\end{array}$ & $\begin{array}{c}1.51 \times 1 \\
0^{-8}\end{array}$ \\
\hline & $\mathrm{E}\left(\mathrm{KJ} / \mathrm{mol}^{1}\right)$ & 5.185 & 6.623 & 5.330 & 7.538 & 6.681 & 5.573 & 8.574 & 6.376 & 5.754 \\
\hline & $\mathrm{R}^{2}$ & 0.409 & 0.479 & 0.857 & 0.391 & 0.699 & 0.975 & 0.521 & 0.857 & 0.988 \\
\hline
\end{tabular}


Table 2 Adsorption capacity of chemically treated rice husk for different dyes

\begin{tabular}{|c|c|c|c|}
\hline Treatment of rice husk & Dye & $\begin{array}{l}\text { Adsorption } \\
\text { capacity }\end{array}$ & References \\
\hline Without any pretreatment & Indigo carmine & $65.90 \mathrm{mg} / \mathrm{g}$ & Lakshmi et al. (2009) \\
\hline Citric acid & Direct F. Scarlet & $\sim 13 \mathrm{mg} / \mathrm{g}$ & $\begin{array}{l}\text { Abdelwahab et al. } \\
(2005)\end{array}$ \\
\hline $\mathrm{H}_{3} \mathrm{PO}_{4}$ & $5 \mathrm{G}$ blue dye & $3.84 \mathrm{mg} / \mathrm{g}$ & $\begin{array}{l}\text { Costa Junior et al. } \\
(2018)\end{array}$ \\
\hline \multirow{2}{*}{ Thermally treated at $75^{\circ} \mathrm{C}$} & Methylene blue & $24.48 \mathrm{mg} / \mathrm{g}$ & Quansah et al. (2020) \\
\hline & Crystal violet & $25.46 \mathrm{mg} / \mathrm{g}$ & Quansah et al. (2020) \\
\hline \multirow{2}{*}{ Oxalic acid } & Methylene blue & $53.2 \mathrm{mg} / \mathrm{g}$ & Zou et al. (2011) \\
\hline & Malachite green & $54.0 \mathrm{mg} / \mathrm{g}$ & Zou et al. (2011) \\
\hline \multirow{3}{*}{ Sodium hydroxide under pressure } & Crystal violet & $44.9 \mathrm{mg} / \mathrm{g}$ & $\begin{array}{l}\text { Chakraborty et al. } \\
\text { (2011) }\end{array}$ \\
\hline & Safranine & $37.9 \mathrm{mg} / \mathrm{g}$ & $\begin{array}{l}\text { Chowdhury et al. } \\
(2012)\end{array}$ \\
\hline & Malachite green & $12.6 \mathrm{mg} / \mathrm{g}$ & $\begin{array}{l}\text { Chowdhury et al. } \\
(2011)\end{array}$ \\
\hline \multirow[t]{2}{*}{$\mathrm{HCl}$} & $\begin{array}{c}\text { Everdirect } \\
\text { Orange-3GL }\end{array}$ & $29.9 \mathrm{mg} / \mathrm{g}$ & Safa et al. (2011) \\
\hline & Direct Blue-67 & $37.9 \mathrm{mg} / \mathrm{g}$ & Safa et al. (2011) \\
\hline \multirow[b]{2}{*}{ EDTA } & Basic blue 3 & $3.3 \mathrm{mg} / \mathrm{g}$ & Ong et al. (2007) \\
\hline & $\begin{array}{l}\text { Reactive orange } \\
16\end{array}$ & $24.9 \mathrm{mg} / \mathrm{g}$ & Ong et al. (2007) \\
\hline Acetic acid and hydrogen peroxide & Rhodamine B & $\begin{array}{c}5.87 \times 10-5 \\
\mathrm{mg} / \mathrm{g}\end{array}$ & Jain et al. (2007) \\
\hline Rise husk ash without pretreatment & Brilliant green & $26.20 \mathrm{mg} / \mathrm{g}$ & Mane et al. (2007) \\
\hline $\begin{array}{l}\text { Effluent from alkaline scouring of } \\
\text { cotton }\end{array}$ & Congo red & $149.1 \mathrm{mg} / \mathrm{g}$ & This work \\
\hline
\end{tabular}

Table 3 Adsorption capacity of Congo red onto different renewable adsorbents

\begin{tabular}{|c|c|c|}
\hline Adsorbent & $\begin{array}{l}\text { Adsorption capacity of } \\
\text { Congo red }\end{array}$ & References \\
\hline Rice hull ash & $171.00 \mathrm{mg} / \mathrm{g}$ & Chou et al. (2001) \\
\hline Powder from eucalyptus leaf & $29.68 \mathrm{mg} / \mathrm{g}$ & Kumari et al (2019) \\
\hline $\begin{array}{l}\text { Pellet of rice hull ash, kaolin and } \\
\text { starch }\end{array}$ & $21.0 \mathrm{mg} / \mathrm{g}$ & Chou et al. (2001) \\
\hline $\begin{array}{l}\text { Hydrothermally treated Shiitake } \\
\text { mushroom }\end{array}$ & $217.86 \mathrm{mg} / \mathrm{g}$ & Yang et al. (2019) \\
\hline Egg shell membrane & $117.65 \mathrm{mg} / \mathrm{g}$ & Parvin et al (2019) \\
\hline Sulfidogenic sludge & $238.90 \mathrm{mg} / \mathrm{g}$ & Rasool and Lee (2013) \\
\hline
\end{tabular}




\begin{tabular}{lcl}
\hline Raw pine cone & $32.65 \mathrm{mg} / \mathrm{g}$ & Dawood and Sen (2012) \\
Acid-treated pine cone & $40.19 \mathrm{mg} / \mathrm{g}$ & Dawood and Sen (2012) \\
Clay materials & $4.3-19.9 \mathrm{mg} / \mathrm{g}$ & Vimonses et al. (2009) \\
Rice husk & $14.00 \mathrm{mg} / \mathrm{g}$ & Han et al. (2008) \\
Calcium rich - fly ash & $4.47 \times 105 \mathrm{~mol} / \mathrm{g}$ & Acemioğlu (2004) \\
Ca-bentonite & $107.41 \mathrm{mg} / \mathrm{g}$ & Lian et al. (2009) \\
Coir pith & $6.72 \mathrm{mg} / \mathrm{g}$ & Namasivayam and Kavitha \\
Orange peel & $22.44 \mathrm{mg} / \mathrm{g}$ & (2002) \\
Powder from jute stick & $35.70 \mathrm{mg} / \mathrm{g}$ & Namasivayam et al. (1996) \\
Dead Aspergillus niger fungus & $14.72 \mathrm{mg} / \mathrm{g}$ & Fu and Viraraghavan (2002) \\
Modified rice husk & $149.1 \mathrm{mg} / \mathrm{g}$ & This work \\
\hline
\end{tabular}

266

267 Adsorption kinetics

268 The amount of adsorbed CR versus the contact time serves to evaluate the adsorption kinetics. It

269 is essential for the examination of the mechanism by which the adsorption occurs. Pseudo-first-

270 order (Eq. 12), pseudo-second-order (Eq. 13), Elovich (Eq. 14), intraparticle diffusion (Eq. 15) as

271 well as the liquid film diffusion (Eq. 16) models are employed in this study to evaluate the

272 kinetics of adsorption.

273

$$
\log \left(Q_{e}-Q_{t}\right)=\log Q_{e}-\frac{k_{1}}{2.303} t
$$

274

$$
\frac{\mathrm{t}}{\mathrm{Q}_{\mathrm{t}}}=\frac{1}{\mathrm{k}_{2} \mathrm{Q}_{\mathrm{e}}^{2}}+\frac{1}{\mathrm{Q}_{\mathrm{e}}} \mathrm{t}
$$

275

$$
\mathrm{Qt}=\frac{1}{\beta} \ln (\alpha \beta)+\frac{1}{\beta} \ln \mathrm{t}
$$

276

$$
\mathrm{Qt}=\mathrm{k}_{\mathrm{i}} \mathrm{t}^{0.5}
$$

277

$$
\ln (1-F)=-\mathrm{k}_{\mathrm{fd}} \mathrm{t}
$$


$278 \mathrm{k}_{1}\left(\mathrm{~min}^{-1}\right)$ and $\mathrm{k}_{2}(\mathrm{~g} / \mathrm{gmin})$ are rate constants for pseudo-first and pseudo-second-order, 279 respectively, Qe $(\mathrm{g} / \mathrm{g})$ is amount of adsorbate at equilibrium and Qt $(\mathrm{g} / \mathrm{g})$ is amount of adsorbate 280 at time $\mathrm{t}, \alpha$ (g/gmin) is the initial sorption rate constant, $\beta(\mathrm{g} / \mathrm{g})$ is desorption constant, $\mathrm{k}_{\mathrm{i}}$ $281\left(\mathrm{~g} / \mathrm{gmin}^{0.5}\right)$ is intraparticle diffusion rate constant, $\mathrm{F}$ is fractional attainment of equilibrium, equal 282 to Qt/Qe and $\mathrm{K}_{\mathrm{fd}}\left(\mathrm{min}^{-1}\right)$ is liquid film diffusion rate constant.

283 The calculated kinetic parameters are presented in Table 4. The coefficients of correlation of the 284 pseudo-second-order vary from 0.9998 to 1, while those of the pseudo-first-order range between 2850.1513 and 0.9128 . The substantially higher coefficients of correlation of the pseudo-second286 order and the small differences between $\mathrm{Q}_{\mathrm{m}}$, exp and $\mathrm{Q}_{\mathrm{m}}$, cal of this kinetic model, reinforce its 287 applicability. The plots $\mathrm{t} / \mathrm{Q}_{\mathrm{t}}$ versus $\mathrm{t}$ of 0.1 to $0.5 \mathrm{~g} / \mathrm{L}$ initial $\mathrm{CR}$ concentration, for $10 \mathrm{~g} / \mathrm{L}$ 288 adsorbent dosage tested at $298 \mathrm{~K}$ show excellent linearity (Fig. 1 in Supplementary file).

289 Pseudo-second-order rate constant $\mathrm{k}_{2}$ is calculated from the intercept of the slope $\mathrm{t} / \mathrm{Qt}$ versus $\mathrm{t}$. 290 Since $k_{2}$ has the highest $\mathrm{R}^{2}$, it is then used for calculation of the initial adsorption rate $\mathrm{h}$ 291 according to Eq. (17). The $\mathrm{k}_{2}$ values increase along the adsorbent dosage and temperature of 292 adsorption testing. Increased $\mathrm{k}_{2}$ at a higher temperature (Table 4) indicates the endothermic 293 process of the adsorption of CR onto ERH when the temperature of adsorption increases 294 (Chowdhury et al. 2011). The $\mathrm{h}$ value, which is the initial adsorption rate, is useful for creating a 295 continuous adsorption system in which a higher initial adsorption rate is crucial for the proper 296 selection of the adsorbents. Higher h values at elevated temperature and higher ERH dosage 297 favor building a continuous adsorption system filled with more ERH that will work at a higher 298 temperature.

$$
h=k_{2} Q e^{2}
$$


The Elovich model is another kinetic model used to examine adsorption/desorption kinetic on the

301 solid adsorbent. This equation assumes the heterogeneous nature of the solid surface active sites

302 that exhibit different activation energies for chemisorption (Chowdhury et al. 2011). The

303 correlation coefficients $\mathrm{R}^{2}$ determined from the Qt vs $\ln (\mathrm{t})$ plots are in the range between 0.4579

304 and 0.9065 (Table 4). In this model, the initial adsorption rate is presented as the constant $\alpha$,

305 while $\beta$ is the surface coverage or desorption constant. These constants are temperature-

306 dependent. An increase in temperature is accompanied by an increase in $\alpha$ and $\beta$, indicating that

307 both the initial adsorption and the available adsorption area would increase. Moreover, the

308 adsorbent dosage also influences the values of $\alpha$ and $\beta$. More rice husk, at the same initial dye

309 concentration, increases both $\alpha$ and $\beta$ constants.

310 During the process of dye adsorption onto some adsorbent, the diffusion of the dye from the bulk 311 dye solution to the surface of the rice husk, and the transport from the surface into the solid rice

312 husk may have occurred. Since these mechanisms follow intraparticle diffusion and liquid film

313 diffusion models, these models have been explored to rate CR adsorption onto ERH. The liquid

314 film diffusion parameters calculated from the plots of $\ln (1-\mathrm{F})$ versus t have $\mathrm{R}^{2}$ between 0.1239

315 and 0.8943 with intercepts ranging from -1.1044 to -4.8625 and $\mathrm{k}_{\mathrm{fd}}$ ranging from -0.0019 to -

$3160.0071 \mathrm{~min}^{-1}$ (Table 4). On the other hand, the intraparticle diffusion parameters calculated from

317 the plots Qt versus $\mathrm{t}^{0.5}$ have $\mathrm{R}^{2}$ between 0.1238 and 0.5339 , intercepts between 0.0097 and

3180.0837 and $\mathrm{k}_{\mathrm{i}}$ ranging from 0.0001 to $0.0073 \mathrm{~g} / \mathrm{gmin}^{0.5}$. Both models show that the intercepts of

319 linear plots did not pass through the origin. Theoretically, if one of these models intends to be the

320 sole rate-determining step, the plots must have zero intercept. Since the linear plots of both

321 models do not meet this requirement, the applicability of these models in the present adsorption 
322 system is limited. In that case, during the interaction of CR with ERH, surface adsorption and

323 intraparticle diffusion could both happen.

324

325 Table 4 Pseudo-first-order and pseudo-second-order kinetic, Elovich, liquid film diffusion and

326 intraparticle diffusion kinetic parameters for adsorption of Congo red onto ERH

\begin{tabular}{|c|c|c|c|c|c|c|c|c|c|c|c|}
\hline \multirow{4}{*}{ Kinetics } & \multirow{4}{*}{$\begin{array}{c}\mathrm{Cog} \\
\mathbf{L}^{-1}\end{array}$} & \multirow{4}{*}{ Parameters } & \multicolumn{9}{|c|}{ Temperature $\left({ }^{\circ} \mathrm{C}\right)$} \\
\hline & & & \multicolumn{3}{|c|}{298} & \multicolumn{3}{|c|}{323} & \multicolumn{3}{|c|}{343} \\
\hline & & & \multicolumn{3}{|c|}{ Adsorbent dosage (g/L) } & \multicolumn{3}{|c|}{ Adsorbent dosage (g/L) } & \multicolumn{3}{|c|}{ Adsorbent dosage (g/L) } \\
\hline & & & 10 & 20 & 40 & 10 & 20 & 40 & 10 & 20 & 40 \\
\hline \multirow{20}{*}{$\begin{array}{l}\text { Pseudo First } \\
\text { order }\end{array}$} & \multirow{4}{*}{0.1} & $\mathrm{Q}_{\mathrm{m}, \exp }(\mathrm{g} / \mathrm{g})$ & 0.0423 & 0.0243 & 0.0122 & 0.0476 & 0.0244 & 0.0123 & 0.0480 & 0.0242 & 0.0122 \\
\hline & & $\mathrm{Q}_{\mathrm{m} \text {, calc }}(\mathrm{g} / \mathrm{g})$ & 0.0070 & 0.0007 & 0.0001 & 0.0047 & 0.0005 & 0.0001 & 0.0035 & 0.0002 & 0.0000 \\
\hline & & $\mathrm{K}_{1}(1 / \mathrm{min})$ & 0.0094 & 0.0094 & 0.0035 & 0.0085 & 0.0039 & 0.0014 & 0.0092 & 0.0076 & 0.0028 \\
\hline & & $\mathrm{R}^{2}$ & 0.7968 & 0.4086 & 0.1513 & 0.6901 & 0.3196 & 0.3043 & 0.7260 & 0.5717 & 0.3854 \\
\hline & \multirow{4}{*}{0.2} & $\mathrm{Q}_{\mathrm{m}, \exp }(\mathrm{g} / \mathrm{g})$ & 0.0643 & 0.0455 & 0.0245 & 0.0807 & 0.0483 & 0.0246 & 0.0884 & 0.0480 & 0.0245 \\
\hline & & $\mathrm{Q}_{\mathrm{m} \text { calc }}(\mathrm{g} / \mathrm{g})$ & 0.0168 & 0.0038 & 0.0006 & 0.0101 & 0.0014 & 0.0003 & 0.0083 & 0.0013 & 0.0002 \\
\hline & & $\mathrm{K}_{1}(1 / \mathrm{min})$ & 0.0101 & 0.0085 & 0.0060 & 0.0122 & 0.0090 & 0.0030 & 0.0117 & 0.0071 & 0.0058 \\
\hline & & $\mathrm{R}^{2}$ & 0.9025 & 0.4530 & 0.3742 & 0.6355 & 0.4318 & 0.3051 & 0.6497 & 0.4875 & 0.4069 \\
\hline & \multirow{4}{*}{0.3} & $\mathrm{Q}_{\mathrm{m}, \exp }(\mathrm{g} / \mathrm{g})$ & 0.0740 & 0.0601 & 0.0365 & 0.0907 & 0.0707 & 0.0368 & 0.1183 & 0.0728 & 0.0367 \\
\hline & & $\mathrm{Q}_{\mathrm{m}, \text { calc }}(\mathrm{g} / \mathrm{g})$ & 0.0162 & 0.0093 & 0.0011 & 0.0139 & 0.0079 & 0.0009 & 0.0340 & 0.0038 & 0.0003 \\
\hline & & $\mathrm{K}_{1}(1 / \mathrm{min})$ & 0.0122 & 0.0157 & 0.0136 & 0.0115 & 0.0120 & 0.0069 & 0.0663 & 0.0092 & 0.0037 \\
\hline & & $\mathrm{R}^{2}$ & 0.9128 & 0.8210 & 0.5948 & 0.7789 & 0.7302 & 0.5402 & 0.8485 & 0.6027 & 0.3539 \\
\hline & \multirow{4}{*}{0.4} & $\mathrm{Q}_{\mathrm{m}, \exp }(\mathrm{g} / \mathrm{g})$ & 0.0849 & 0.0663 & 0.0480 & 0.0952 & 0.0838 & 0.0489 & 0.1266 & 0.0925 & 0.0489 \\
\hline & & $\mathrm{Q}_{\mathrm{m}, \text { calc }}(\mathrm{g} / \mathrm{g})$ & 0.0240 & 0.0090 & 0.0035 & 0.0129 & 0.0076 & 0.0012 & 0.0112 & 0.0073 & 0.0007 \\
\hline & & $\mathrm{K}_{1}(1 / \mathrm{min})$ & 0.0111 & 0.0099 & 0.0111 & 0.0131 & 0.0129 & 0.0076 & 0.0117 & 0.0097 & 0.0071 \\
\hline & & $\mathrm{R}^{2}$ & 0.9090 & 0.6277 & 0.6477 & 0.8233 & 0.6836 & 0.4537 & 0.7062 & 0.6257 & 0.4877 \\
\hline & \multirow{4}{*}{0.5} & $\mathrm{Q}_{\mathrm{m}, \exp }(\mathrm{g} / \mathrm{g})$ & 0.0918 & 0.0765 & 0.0580 & 0.1153 & 0.0993 & 0.0609 & 0.1491 & 0.1127 & 0.0611 \\
\hline & & $\mathrm{Q}_{\mathrm{m}, \text { calc }}(\mathrm{g} / \mathrm{g})$ & 0.0245 & 0.0107 & 0.0056 & 0.0106 & 0.0122 & 0.0023 & 0.0149 & 0.0094 & 0.0010 \\
\hline & & $\mathrm{K}_{1}(1 / \mathrm{min})$ & 0.0104 & 0.0120 & 0.0092 & 0.0117 & 0.0108 & 0.0083 & 0.0124 & 0.0111 & 0.0064 \\
\hline & & $\mathrm{R}^{2}$ & 0.8616 & 0.6595 & 0.5333 & 0.6938 & 0.6140 & 0.5142 & 0.6967 & 0.6084 & 0.4579 \\
\hline \multirow{24}{*}{$\begin{array}{l}\text { Pseudo } \\
\text { Second } \\
\text { order }\end{array}$} & \multirow{5}{*}{0.1} & $\mathrm{Q}_{\mathrm{m}, \exp }(\mathrm{g} / \mathrm{g})$ & 0.0423 & 0.0243 & 0.0122 & 0.0476 & 0.0244 & 0.0123 & 0.0480 & 0.0242 & 0.0122 \\
\hline & & $\mathrm{Q}_{\mathrm{m}, \text { calc }}(\mathrm{g} / \mathrm{g})$ & 0.0426 & 0.0244 & 0.0122 & 0.0478 & 0.0243 & 0.0122 & 0.0489 & 0.0242 & 0.0122 \\
\hline & & $\mathrm{K}_{2}(\mathrm{~g} / \mathrm{g} \min )$ & 2.5031 & 11.7048 & 213.27 & 3.6212 & 48.0349 & 544.69 & 5.4947 & 81.2551 & 792.0172 \\
\hline & & $\mathrm{h}(\mathrm{g} / \mathrm{g} \min )$ & 0.00454 & 0.00695 & 0.0317 & 0.0083 & 0.0284 & 0.0815 & 0.0131 & 0.0476 & 0.1176 \\
\hline & & $\mathrm{R}^{2}$ & 0.9999 & 1 & 1 & 1 & 1 & 1 & 1 & 1 & 1 \\
\hline & \multirow{5}{*}{0.2} & $\mathrm{Q}_{\mathrm{m}, \exp }(\mathrm{g} / \mathrm{g})$ & 0.0643 & 0.0455 & 0.0245 & 0.0807 & 0.0483 & 0.0246 & 0.0884 & 0.0480 & 0.0245 \\
\hline & & $\mathrm{Q}_{\mathrm{m}, \text { calc }}(\mathrm{g} / \mathrm{g})$ & 0.0650 & 0.0458 & 0.0245 & 0.0816 & 0.0484 & 0.0245 & 0.0890 & 0.0480 & 0.0245 \\
\hline & & $\mathrm{K}_{2}(\mathrm{~g} / \mathrm{g} \min )$ & 1.0589 & 2.8235 & 27.143 & 0.9756 & 7.2143 & 99.52 & 1.4852 & 13.5242 & 124.6615 \\
\hline & & $\mathrm{h}(\mathrm{g} / \mathrm{g} \min )$ & 0.00447 & 0.00591 & 0.0163 & 0.0065 & 0.0169 & 0.0598 & 0.0117 & 0.0312 & 0.0748 \\
\hline & & $\mathrm{R}^{2}$ & 0.9999 & 0.9999 & 1 & 0.9998 & 1 & 1 & 0.9999 & 1 & 1 \\
\hline & & $\mathrm{Q}_{\mathrm{m}, \exp }(\mathrm{g} / \mathrm{g})$ & 0.0740 & 0.0601 & 0.0365 & 0.0907 & 0.0707 & 0.0368 & 0.1183 & 0.0728 & 0.0367 \\
\hline & & $\mathrm{Q}_{\mathrm{m}, \text { calc }}(\mathrm{g} / \mathrm{g})$ & 0.0747 & 0.0607 & 0.0366 & 0.0915 & 0.0712 & 0.0368 & 0.1191 & 0.0730 & 0.0367 \\
\hline & 0.3 & $\mathrm{~K}_{2}(\mathrm{~g} / \mathrm{g} \min )$ & 1.910 & 1.6263 & 9.5558 & 1.1164 & 1.8351 & 20.999 & 1.2040 & 4.3465 & 84.8913 \\
\hline & & $\mathrm{h}(\mathrm{g} / \mathrm{g} \min )$ & 0.00665 & 0.00597 & 0.0128 & 0.0093 & 0.0093 & 0.0284 & 0.0170 & 0.0231 & 0.1141 \\
\hline & & $\mathrm{R}^{2}$ & 0.9999 & 0.9999 & 1 & 0.9999 & 0.9999 & 1 & 0.9999 & 1 & 1 \\
\hline & & $\mathrm{Q}_{\mathrm{m}, \exp }(\mathrm{g} / \mathrm{g})$ & 0.0849 & 0.0663 & 0.0480 & 0.0952 & 0.0838 & 0.0489 & 0.1266 & 0.0925 & 0.0489 \\
\hline & & $\mathrm{Q}_{\mathrm{m}, \text { calc }}(\mathrm{g} / \mathrm{g})$ & 0.0859 & 0.0669 & 0.0482 & 0.0959 & 0.0844 & 0.0489 & 0.1273 & 0.0929 & 0.0489 \\
\hline & 0.4 & $\mathrm{~K}_{2}(\mathrm{~g} / \mathrm{g} \min )$ & 0.7276 & 1.3883 & 3.8688 & 1.3306 & 1.6509 & 12.234 & 1.2279 & 2.0108 & 27.7785 \\
\hline & & $\mathrm{h}(\mathrm{g} / \mathrm{g} \min )$ & 0.00537 & 0.00621 & 0.0089 & 0.0122 & 0.0117 & 0.0293 & 0.0199 & 0.0173 & 0.0664 \\
\hline & & $\mathrm{R}^{2}$ & 0.9998 & 0.9999 & 1 & 0.9999 & 0.9999 & 1 & 0.9999 & 1 & 1 \\
\hline & & $\mathrm{Q}_{\mathrm{m}, \exp }(\mathrm{g} / \mathrm{g})$ & 0.0918 & 0.0765 & 0.0580 & 0.1153 & 0.0993 & 0.0609 & 0.1491 & 0.1127 & 0.0611 \\
\hline & 05 & $\mathrm{Q}_{\mathrm{m}, \text { calc }}(\mathrm{g} / \mathrm{g})$ & 0.0931 & 0.0774 & 0.0583 & 0.1161 & 0.1003 & 0.0610 & 0.1502 & 0.1133 & 0.0611 \\
\hline & 0.5 & $\mathrm{~K}_{2}(\mathrm{~g} / \mathrm{g} \min )$ & 0.6251 & 0.9624 & 2.3022 & 1.1533 & 0.9186 & 6.3240 & 0.8527 & 1.3768 & 19.2968 \\
\hline & & $\mathrm{h}(\mathrm{g} / \mathrm{g} \min )$ & 0.00541 & 0.00577 & 0.0078 & 0.0155 & 0.0092 & 0.0235 & 0.0192 & 0.0177 & 0.0720 \\
\hline
\end{tabular}




\begin{tabular}{|c|c|c|c|c|c|c|c|c|c|c|c|}
\hline & & $\mathrm{R}^{2}$ & 0.9997 & 0.9998 & 0.9999 & 0.9999 & 0.9999 & 1 & 0.9999 & 1 & 1 \\
\hline \multirow{14}{*}{ Elovich } & \multirow{3}{*}{0.1} & $\alpha(\mathrm{g} / \mathrm{g} \min )$ & 0.0225 & 0.0316 & 0.0894 & 0.0410 & 0.1475 & 0.1781 & 0.0835 & 0.2119 & 0.1781 \\
\hline & & $\beta(g / g)$ & 169.49 & 322.58 & 769.23 & 158.73 & 384.61 & 833.33 & 166.67 & 400.00 & 833.33 \\
\hline & & $\mathrm{R}^{2}$ & 0.8476 & 0.7309 & 0.5261 & 0.7842 & 0.561 & 0.4636 & 0.7140 & 0.5169 & 0.4579 \\
\hline & \multirow{3}{*}{0.2} & $\alpha(\mathrm{g} / \mathrm{g} \min )$ & 0.0217 & 0.0247 & 0.0804 & 0.0266 & 0.0808 & 0.2389 & 0.0516 & 0.1709 & 0.2804 \\
\hline & & $\beta(g / g)$ & 107.53 & 158.73 & 357.14 & 84.745 & 166.67 & 400.00 & 81.967 & 181.82 & 400.00 \\
\hline & & $\mathrm{R}^{2}$ & 0.8977 & 0.8327 & 0.6296 & 0.8781 & 0.7063 & 0.5066 & 0.8270 & 0.6117 & 0.4801 \\
\hline & \multirow{2}{*}{0.3} & $\alpha(\mathrm{g} / \mathrm{g} \min )$ & 0.0319 & 0.0276 & 0.0662 & 0.0441 & 0.0437 & 0.1630 & 0.0813 & 0.1335 & 0.3606 \\
\hline & & $\mathrm{R}^{2}$ & 0.8670 & 0.8674 & 0.7011 & 0.8619 & 0.8300 & 0.5917 & 0.8200 & 0.7031 & 0.4984 \\
\hline & \multirow{3}{*}{0.4} & $\alpha(\mathrm{g} / \mathrm{g} \min )$ & 0.0241 & 0.0272 & 0.0451 & 0.0576 & 0.0511 & 0.1607 & 0.0886 & 0.0939 & 0.3576 \\
\hline & & $\beta(g / g)$ & 80.000 & 105.26 & 158.73 & 76.336 & 86.207 & 178.57 & 58.139 & 83.33 & 192.31 \\
\hline & & $\mathrm{R}^{2}$ & 0.9065 & 0.8703 & 0.7861 & 0.8305 & 0.8182 & 0.6324 & 0.8053 & 0.7827 & 0.5351 \\
\hline & \multirow{3}{*}{0.5} & $\alpha(\mathrm{g} / \mathrm{g} \min )$ & 0.0224 & 0.0221 & 0.0375 & 0.0626 & 0.0394 & 0.1123 & 0.0813 & 0.0918 & 0.3658 \\
\hline & & $\beta(g / g)$ & 72.464 & 86.956 & 126.58 & 61.728 & 69.930 & 133.33 & 47.847 & 67.114 & 151.52 \\
\hline & & $\mathrm{R}^{2}$ & 0.8983 & 0.8730 & 0.8295 & 0.8119 & 0.8707 & 0.6866 & 0.8271 & 0.8091 & 0.5574 \\
\hline \multirow{14}{*}{$\begin{array}{l}\text { Liquid film } \\
\text { diffusion }\end{array}$} & \multirow[t]{2}{*}{0.1} & $\mathrm{~K}_{\mathrm{fd}}\left(\min ^{-1}\right)$ & -0.0062 & -0.0046 & -0.0022 & -0.004 & -0.0022 & -0.0012 & -0.0044 & -0.0039 & -0.0019 \\
\hline & & $\mathrm{R}^{2}$ & 0.666 & 0.42 & 0.1663 & 0.6607 & 0.2814 & 0.1239 & 0.6812 & 0.4722 & 0.1854 \\
\hline & \multirow{3}{*}{0.2} & intercept & -1.176 & -2.1745 & -3.298 & -1.8155 & -3.0959 & -3.7368 & -2.0718 & -3.1518 & -4.3885 \\
\hline & & $\mathrm{K}_{\mathrm{fd}}\left(\mathrm{min}^{-1}\right)$ & -0.0046 & -0.004 & -0.0031 & -0.0056 & -0.0043 & -0.0019 & -0.0054 & -0.0036 & -0.0031 \\
\hline & & $\mathrm{R}^{2}$ & 0.8822 & 0.4656 & 0.3599 & 0.641 & 0.4346 & 0.2315 & 0.6474 & 0.4532 & 0.3329 \\
\hline & \multirow{3}{*}{0.3} & intercept & -1.327 & -1.6304 & -3.0425 & -1.6373 & -1.9123 & -3.2495 & -1.0882 & -2.5725 & -4.2502 \\
\hline & & $\mathrm{K}_{\mathrm{fd}}\left(\mathrm{min}^{-1}\right)$ & -0.0055 & -0.0071 & -0.0063 & -0.0053 & -0.0055 & -0.0035 & -0.029 & -0.0043 & -0.0023 \\
\hline & & $\mathrm{R}^{2}$ & 0.8936 & 0.8158 & 0.5894 & 0.7674 & 0.7199 & 0.4741 & 0.8543 & 0.579 & 0.2538 \\
\hline & \multirow{3}{*}{0.4} & intercept & -1.1044 & -1.7508 & -2.2821 & -1.7492 & -2.104 & -3.2266 & 2.1207 & -2.2223 & -3.7363 \\
\hline & & $\mathrm{K}_{\mathrm{fd}}\left(\min ^{-1}\right)$ & -0.005 & -0.0046 & -0.0052 & -0.0059 & -0.0059 & -0.0038 & -0.0054 & -0.0045 & -0.0037 \\
\hline & & $\mathrm{R}^{2}$ & 0.8943 & 0.6286 & 0.6381 & 0.8076 & 0.6793 & 0.4364 & 0.6934 & 0.6132 & 0.4327 \\
\hline & \multirow{3}{*}{0.5} & intercept & -1.1541 & -1.7181 & -2.0518 & -2.0873 & -1.8319 & -2.8644 & 2.0112 & -2.1746 & -3.6082 \\
\hline & & $\mathrm{K}_{\mathrm{fd}}\left(\min ^{-1}\right)$ & -0.0047 & -0.0055 & -0.0043 & -0.0054 & -0.005 & -0.004 & -0.0057 & -0.0051 & -0.0034 \\
\hline & & $\mathrm{R}^{2}$ & 0.8487 & 0.6634 & 0.5556 & 0.6835 & 0.6185 & 0.4954 & 0.691 & 0.6075 & 0.4076 \\
\hline \multirow{13}{*}{$\begin{array}{c}\text { Intraparticle } \\
\text { diffusion }\end{array}$} & 0.1 & intercept & 0.0232 & 0.0158 & 0.0094 & 0.0289 & 0.0183 & 0.0097 & 0.0325 & 0.0187 & 0.0097 \\
\hline & \multirow{3}{*}{0.2} & intercept & 0.0313 & 0.0256 & 0.0176 & 0.0397 & 0.0324 & 0.019 & 0.0501 & 0.0347 & 0.0193 \\
\hline & & $\mathrm{K}_{\mathrm{i}}\left(\mathrm{g} / \mathrm{g} \min ^{0.5}\right)$ & 0.0012 & 0.0008 & 0.0003 & 0.0016 & 0.0007 & 0.0002 & 0.0015 & 0.0006 & 0.0002 \\
\hline & & $\mathrm{R}^{2}$ & 0.509 & 0.4088 & 0.216 & 0.4904 & 0.2736 & 0.1463 & 0.4008 & 0.2102 & 0.1348 \\
\hline & \multirow{3}{*}{0.3} & intercept & 0.0388 & 0.032 & 0.0247 & 0.0488 & 0.0403 & 0.0271 & 0.0688 & 0.049 & 0.0286 \\
\hline & & $\mathrm{K}_{\mathrm{i}}\left(\mathrm{g} / \mathrm{g} \min ^{0.5}\right)$ & 0.0014 & 0.0011 & 0.0005 & 0.0016 & 0.0012 & 0.0004 & 0.002 & 0.001 & 0.0004 \\
\hline & & $\mathrm{R}^{2}$ & 0.4577 & 0.4559 & 0.2700 & 0.4669 & 0.4024 & 0.193 & 0.3899 & 0.273 & 0.1412 \\
\hline & \multirow{3}{*}{0.4} & intercept & 0.0395 & 0.0344 & 0.0295 & 0.0541 & 0.0481 & 0.035 & 0.0745 & 0.0572 & 0.0373 \\
\hline & & $\mathrm{K}_{\mathrm{i}}\left(\mathrm{g} / \mathrm{g} \min ^{0.5}\right)$ & 0.0073 & 0.0012 & 0.0007 & 0.0016 & 0.0014 & 0.0006 & 0.0021 & 0.0014 & 0.0005 \\
\hline & & $\mathrm{R}^{2}$ & 0.5311 & 0.4656 & 0.3498 & 0.4039 & 0.3904 & 0.2192 & 0.3744 & 0.347 & 0.162 \\
\hline & \multirow{3}{*}{0.5} & intercept & 0.0412 & 0.0366 & 0.0333 & 0.065 & 0.0513 & 0.0415 & 0.0837 & 0.0672 & 0.046 \\
\hline & & $\mathrm{K}_{\mathrm{i}}\left(\mathrm{g} / \mathrm{g} \min ^{0.5}\right)$ & 0.0019 & 0.0015 & 0.001 & 0.002 & 0.0019 & 0.0008 & 0.0026 & 0.0018 & 0.0007 \\
\hline & & $\mathrm{R}^{2}$ & 0.5339 & 0.4918 & 0.4013 & 0.3911 & 0.4663 & 0.2583 & 0.4031 & 0.3758 & 0.1732 \\
\hline
\end{tabular}

327

330 The activation energy Ea is a crucial parameter for determining the origin of the sorption forces 331 that bind the sorbate and sorbent. Since physical adsorption contains weak forces, Ea is lower 332 than $40 \mathrm{KJ} / \mathrm{mol}$. As chemical adsorption involves much stronger forces than physical adsorption, 
Ea is higher than $40 \mathrm{KJ} / \mathrm{mol}$. The activation energy for adsorption of CR onto ERH is determined by the Arrhenius equation (Eq. 17) (Zhu et al 2009).

$$
\ln k=\ln A-\frac{\mathrm{Ea}}{R T}
$$

$\mathrm{k}$ is the rate constant, $\mathrm{A}$ is the Arrhenius constant, $\mathrm{Ea}(\mathrm{kJ} / \mathrm{mol})$ is the activation energy, $\mathrm{R}(8.314$ $\mathrm{J} / \mathrm{mol} \mathrm{K}$ ) is the gas constant and $\mathrm{T}(\mathrm{K})$ is the temperature. In this study, Ea was obtained from the slope of the linear plot of $\ln \mathrm{k}_{2}$ (calculated from the pseudo-second-order kinetic model) versus $1 / \mathrm{T}$.

The Eyring equation (Eq. 18) was also used to determine the standard enthalpy of activation $\left(\Delta \mathrm{H}^{\#}\right)$, the entropy of activation $\left(\Delta \mathrm{S}^{\#}\right)$ and free energy of activation $\left(\Delta \mathrm{G}^{\#}\right)$ in the sorption process (Saha and Chowdhury 2011; Chowdhury et al. 2010):

$$
\ln \frac{k}{T}=\ln \frac{k_{B}}{h}+\frac{\Delta S^{\#}}{R}-\frac{\Delta H^{\#}}{R T}
$$

where $\mathrm{k}$ is the rate constant, $\mathrm{T}$ is the temperature $(\mathrm{K}), \mathrm{k}_{\mathrm{B}}$ is the Boltzman constant $(1.3807 \times$ $\left.10^{-23} \mathrm{~J} / \mathrm{K}\right), \mathrm{h}$ is the Planck constant $\left(6.6261 \times 10^{-34} \mathrm{~J} \mathrm{~s}\right)$ and $\mathrm{R}$ is the gas constant. By plotting $\mathrm{ln}$ $\left(\mathrm{k}_{2} / \mathrm{T}\right)$ vs $1 / \mathrm{T}$, the values of $\Delta \mathrm{H}^{\#}$ and $\Delta \mathrm{S}^{\#}$ were determined from the slope and intercept of the plot, respectively. The free energy of activation $\left(\Delta G^{\#}\right)$ was calculated by using these values in the following equation:

$$
\Delta \mathrm{G}^{\#}=\Delta \mathrm{H}^{\#}-\mathrm{T} \Delta \mathrm{S}^{\#}
$$

The results of Eyring's thermodynamic parameters and energy of activation shown in Table 5 indicate positive $\Delta \mathrm{G}^{\#}$, positive $\Delta \mathrm{H}^{\#}$, and negative $\Delta \mathrm{S}^{\#}$. Positive $\Delta \mathrm{G}^{\#}$ suggests a requirement of energy to convert reactants into products during the adsorption reaction. The positive $\Delta \mathrm{H}^{\#}$ indicates an endothermic reaction. The negative $\Delta S^{\#}$ suggests an associative mechanism of $C R$ adsorption onto ERH in which dye molecules are intact. The negative $\Delta \mathrm{S}^{\#}$ values are also an indication of a lack of significant change in the adsorbent's internal structures during the adsorption (Chowdhury et al. 2011; Chowdhury et al. 2012), meaning the ERH can be reused. The obtained Ea values for the adsorption of CR onto ERH, for all initial concentrations $(\mathrm{g} / \mathrm{L})$ and adsorbent mass (g), suggest that the adsorption process is, in fact, physisorption. 
Table 5 Activation parameters for adsorption of Congo red onto ERH

\begin{tabular}{|c|c|c|c|c|c|c|c|c|c|c|c|}
\hline \multirow{4}{*}{ Model } & \multirow{4}{*}{$\begin{array}{c}\text { Initial } \\
\operatorname{conc}(\mathrm{g} / \mathrm{L})\end{array}$} & \multirow{4}{*}{ Parameters } & \multicolumn{9}{|c|}{ Temperature (K) } \\
\hline & & & \multicolumn{3}{|c|}{298} & \multicolumn{3}{|c|}{323} & \multirow{2}{*}{\multicolumn{3}{|c|}{$\begin{array}{c}343 \\
\text { Adsorbent dosage (g/L) }\end{array}$}} \\
\hline & & & \multicolumn{3}{|c|}{ Adsorbent dosage (g/L) } & \multicolumn{3}{|c|}{ Adsorbent dosage (g/L) } & & & \\
\hline & & & 10 & 20 & 40 & 10 & 20 & 40 & 10 & 20 & 40 \\
\hline \multirow{25}{*}{ Eyring } & \multirow{5}{*}{0.1} & $\Delta \mathrm{G} \#(\mathrm{~kJ} / \mathrm{mol})$ & 70.77 & 66.70 & 59.58 & 75.70 & 69.40 & 62.70 & 79.65 & 71.56 & 65.18 \\
\hline & & $\Delta \mathrm{H} \#(\mathrm{~kJ} / \mathrm{mol})$ & 11.98 & 34.54 & 22.49 & & & & & & \\
\hline & & $\Delta \mathrm{S} \#(\mathrm{~J} / \mathrm{mol} \mathrm{K})$ & -197.26 & -107.93 & -124.47 & & & & & & \\
\hline & & $\mathrm{Ea}(\mathrm{kJ} / \mathrm{mol})$ & 14.64 & 37.18 & 25.14 & & & & & & \\
\hline & & $\mathrm{R}^{2}$ & 0.9809 & 0.9763 & 0.9807 & & & & & & \\
\hline & \multirow{5}{*}{0.2} & $\Delta \mathrm{G}^{\#}(\mathrm{~kJ} / \mathrm{mol})$ & 73.03 & 70.39 & 64.53 & 78.89 & 74.04 & 67.68 & 83.58 & 76.95 & 70.20 \\
\hline & & $\Delta \mathrm{H}^{\#}(\mathrm{~kJ} / \mathrm{mol})$ & 3.108 & 26.96 & 27.03 & & & & & & \\
\hline & & $\Delta \mathrm{S}^{\#}(\mathrm{~J} / \mathrm{mol} \mathrm{K})$ & -234.63 & -145.76 & -125.84 & & & & & & \\
\hline & & $\mathrm{Ea}(\mathrm{kJ} / \mathrm{mol})$ & 5.76 & 29.61 & 29.68 & & & & & & \\
\hline & & $\mathrm{R}^{2}$ & 0.4734 & 0.9999 & 0.9221 & & & & & & \\
\hline & \multirow{5}{*}{0.3} & $\Delta \mathrm{G}^{\#}(\mathrm{~kJ} / \mathrm{mol})$ & 72.595 & 72.09 & 67.72 & 78.90 & 76.88 & 70.26 & 83.95 & 80.72 & 72.29 \\
\hline & & $\Delta \mathrm{H}^{\#}(\mathrm{~kJ} / \mathrm{mol})$ & -2.61 & 14.92 & 37.47 & & & & & & \\
\hline & & $\Delta \mathrm{S}^{\#}(\mathrm{~J} / \mathrm{mol} \mathrm{K})$ & -252.35 & -191.84 & -101.51 & & & & & & \\
\hline & & $\mathrm{Ea}(\mathrm{kJ} / \mathrm{mol})$ & 0.045 & 17.57 & 40.12 & & & & & & \\
\hline & & $\mathrm{R}^{2}$ & 0.0009 & 0.7593 & 0.9323 & & & & & & \\
\hline & \multirow{5}{*}{0.4} & $\Delta \mathrm{G}^{\#}(\mathrm{~kJ} / \mathrm{mol})$ & 73.57 & 72.20 & 69.64 & 79.08 & 77.90 & 72.58 & 83.49 & 82.46 & 74.93 \\
\hline & & $\Delta \mathrm{H}^{\#}(\mathrm{~kJ} / \mathrm{mol})$ & 7.89 & 4.24 & 34.55 & & & & & & \\
\hline & & $\Delta \mathrm{S}^{\#}(\mathrm{~J} / \mathrm{mol} \mathrm{K})$ & -220.40 & -228.03 & -117.74 & & & & & & \\
\hline & & $\mathrm{Ea}(\mathrm{kJ} / \mathrm{mol})$ & 10.54 & 6.89 & 37.20 & & & & & & \\
\hline & & $\mathrm{R}^{2}$ & 0.7331 & 0.9803 & 1 & & & & & & \\
\hline & \multirow{5}{*}{0.5} & $\Delta \mathrm{G}^{\#}(\mathrm{~kJ} / \mathrm{mol})$ & 73.86 & 73.25 & 71.08 & 79.70 & 79.10 & 73.94 & 84.38 & 83.78 & 76.23 \\
\hline & & $\Delta \mathrm{H}^{\#}(\mathrm{~kJ} / \mathrm{mol})$ & 4.17 & 3.54 & 36.95 & & & & & & \\
\hline & & $\Delta \mathrm{S}^{\#}(\mathrm{~J} / \mathrm{mol} \mathrm{K})$ & -233.84 & -233.94 & -114.51 & & & & & & \\
\hline & & $\mathrm{Ea}(\mathrm{kJ} / \mathrm{mol})$ & 6.82 & 6.18 & 39.60 & & & & & & \\
\hline & & $\mathrm{R}^{2}$ & 0.3519 & 0.5529 & 0.9827 & & & & & & \\
\hline
\end{tabular}

Van Hoff's classical equation (Eq. 20) is used to calculate the change in Gibbs free energy which

364 is crucial for determining the spontaneity of a process (Saha and Chowdhury 2011):

$$
\Delta \mathrm{G}^{0}=-\mathrm{RT} \ln \mathrm{K}_{\mathrm{C}}
$$

366 where $\mathrm{R}(\mathrm{J} / \mathrm{mol} \mathrm{K})$ is the universal gas constant, $\mathrm{T}(\mathrm{K})$ is the absolute temperature and $\mathrm{K}_{\mathrm{C}}$ is the 367 distribution coefficient for adsorption defined by the Eq. 21:

$$
\mathrm{K}_{\mathrm{C}}=\frac{C a}{C e}
$$

369 in which $\mathrm{Ca}(\mathrm{g} / \mathrm{L})$ is the equilibrium dye concentration on the adsorbent and $\mathrm{Ce}(\mathrm{g} / \mathrm{L})$ is the 370 equilibrium dye concentration in solution. The enthalpy $\left(\Delta \mathrm{H}^{0}\right)$ and entropy $\left(\Delta \mathrm{S}^{0}\right)$ were calculated 371 using the Eq. 22. 
373 By plotting $\Delta \mathrm{G}^{0}$ vs $\mathrm{T}$, the values of $\Delta \mathrm{H}^{0}$ and $\Delta \mathrm{S}^{0}$ were determined from the intercept and slope of

374 the plot, respectively. The calculated values of the thermodynamic parameters for the adsorption 375 of CR onto ERH at all temperatures are listed in Table 6.

376 Table 6 Thermodynamic parameters for adsorption of Congo red onto ERH.

\begin{tabular}{|c|c|c|c|c|c|c|c|c|c|c|c|}
\hline \multirow{4}{*}{ Model } & \multirow{4}{*}{ Initial con. $(\mathrm{g} / \mathrm{L})$} & \multirow{4}{*}{ Parameters } & \multicolumn{9}{|c|}{ Temperature (K) } \\
\hline & & & & 298 & & \multirow{2}{*}{\multicolumn{3}{|c|}{$\frac{323}{\text { Adsorbent dosage (g/L) }}$}} & \multirow{2}{*}{\multicolumn{3}{|c|}{$\frac{343}{\text { Adsorbent dosage (g/L) }}$}} \\
\hline & & & \multicolumn{3}{|c|}{ Adsorbent dosage $(\mathrm{g} / \mathrm{L})$} & & & & & & \\
\hline & & & 10 & 20 & 40 & 10 & 20 & 40 & 10 & 20 & 40 \\
\hline \multirow{25}{*}{$\begin{array}{l}\text { Thermo } \\
\text { dynamic }\end{array}$} & \multirow{5}{*}{0.1} & $\mathrm{~K}_{\mathrm{C}}$ & 5.46 & 34.16 & 38.78 & 19.41 & 34.79 & 44.93 & 39.81 & 30.06 & 38.79 \\
\hline & & $\Delta \mathrm{G}^{0}(\mathrm{~kJ} / \mathrm{mol})$ & -4.21 & -8.74 & -9.06 & -7.96 & -9.53 & -10.22 & -10.51 & -9.70 & -10.43 \\
\hline & & $\Delta \mathrm{H}^{0}(\mathrm{~kJ} / \mathrm{mol})$ & 37.55 & 2.37 & 0.0780 & & & & & & \\
\hline & & $\Delta \mathrm{S}^{0}(\mathrm{~J} / \mathrm{mol} \mathrm{K})$ & 140.4 & 21.7 & 31.07 & & & & & & \\
\hline & & $\mathrm{R}^{2}$ & 0.9978 & 0.9188 & 0.9046 & & & & & & \\
\hline & \multirow{5}{*}{0.2} & $\mathrm{~K}_{\mathrm{C}}$ & 1.79 & 9.91 & 45.51 & 4.17 & 27.98 & 50.28 & 7.60 & 23.39 & 47.78 \\
\hline & & $\Delta \mathrm{G}^{0}(\mathrm{~kJ} / \mathrm{mol})$ & -1.45 & -5.68 & -9.46 & -3.84 & -8.95 & -10.52 & -5.78 & -8.99 & -11.03 \\
\hline & & $\Delta \mathrm{H}^{0}(\mathrm{~kJ} / \mathrm{mol})$ & 27.24 & 16.49 & 0.955 & & & & & & \\
\hline & & $\Delta \mathrm{S}^{0}(\mathrm{~J} / \mathrm{mol} \mathrm{K})$ & 96.2 & 75.8 & 35.14 & & & & & & \\
\hline & & $\mathrm{R}^{2}$ & 1 & 0.8121 & 0.9811 & & & & & & \\
\hline & \multirow{5}{*}{0.3} & $\mathrm{~K}_{\mathrm{C}}$ & 0.97 & 4.03 & 36.45 & 1.53 & 16.39 & 50.72 & 3.73 & 32.33 & 43.12 \\
\hline & & $\Delta \mathrm{G}^{0}(\mathrm{~kJ} / \mathrm{mol})$ & 0.067 & -3.45 & -8.91 & -1.14 & -7.51 & -10.54 & -3.76 & -9.91 & -10.73 \\
\hline & & $\Delta \mathrm{H}^{0}(\mathrm{~kJ} / \mathrm{mol})$ & 25.20 & 39.40 & 3.29 & & & & & & \\
\hline & & $\Delta \mathrm{S}^{0}(\mathrm{~J} / \mathrm{mol} \mathrm{K})$ & 83.4 & 144.3 & 41.56 & & & & & & \\
\hline & & $\mathrm{R}^{2}$ & 0.9269 & 0.9932 & 0.8726 & & & & & & \\
\hline & \multirow{5}{*}{0.4} & $\mathrm{~K}_{\mathrm{C}}$ & 0.74 & 1.96 & 23.84 & 0.91 & 5.17 & 42.96 & 1.72 & 12.24 & 43.44 \\
\hline & & $\Delta \mathrm{G}^{0}(\mathrm{~kJ} / \mathrm{mol})$ & 0.76 & -1.67 & -7.86 & 0.258 & -4.41 & -10.1 & -1.55 & -7.14 & -10.76 \\
\hline & & $\Delta \mathrm{H}^{0}(\mathrm{~kJ} / \mathrm{mol})$ & 15.89 & 34.53 & 11.45 & & & & & & \\
\hline & & $\Delta \mathrm{S}^{0}(\mathrm{~J} / \mathrm{mol} \mathrm{K})$ & 50.0 & 121.2 & 65.42 & & & & & & \\
\hline & & $\mathrm{R}^{2}$ & 0.8613 & 0.996 & 0.9429 & & & & & & \\
\hline & \multirow{5}{*}{0.5} & $\mathrm{~K}_{\mathrm{C}}$ & 0.58 & 1.57 & 12.66 & 0.86 & 3.85 & 36.88 & 1.48 & 9.12 & 42.10 \\
\hline & & $\Delta \mathrm{G}^{0}(\mathrm{~kJ} / \mathrm{mol})$ & 1.35 & -1.13 & -6.29 & 0.418 & -3.62 & -9.69 & -1.11 & -6.30 & -10.66 \\
\hline & & $\Delta \mathrm{H}^{0}(\mathrm{~kJ} / \mathrm{mol})$ & 17.59 & 33.08 & 22.88 & & & & & & \\
\hline & & $\Delta \mathrm{S}^{0}(\mathrm{~J} / \mathrm{mol} \mathrm{K})$ & 54.1 & 114.4 & 98.83 & & & & & & \\
\hline & & $\mathrm{R}^{2}$ & 0.9593 & 0.9928 & 0.9411 & & & & & & \\
\hline
\end{tabular}

378 The negative $\Delta \mathrm{G}^{0}$ values for most of the tested samples indicate a spontaneous adsorption

379 process of $\mathrm{CR}$ onto ERH. The positive $\Delta \mathrm{G}^{0}$ for $\mathrm{ERH}$ tested at $10 \mathrm{~g} / \mathrm{L}$ adsorption dosage and 0.3 ,

3800.4 , and $0.5 \mathrm{~g} / \mathrm{L}$ initial CR concentration show non-spontaneous adsorption of these samples. The

381 inverse correlation between $\Delta \mathrm{G}^{0}$ and the temperature imply more favorable adsorption at high

382 temperatures. The positive $\Delta \mathrm{H}^{0}$ indicates an endothermic reaction of adsorption. The positive 383 values of $\Delta S^{0}$ show the modified rice husk's affinity for CR, an increase in the degree of freedom 
384 of the adsorbed dye, and increased randomness at the solid/solution interface (Gedam et al.

385 2019).

387 Isosteric heat of adsorption $\left(\Delta \mathrm{H}_{\mathrm{X}}, \mathrm{KJ} / \mathrm{mol}\right)$, presented as the heat of adsorption at a constant 388 amount of adsorbed adsorbate, is of great importance for obtaining an optimized adsorption 389 process. The Clausius-Clapeyron equation is used to estimate this thermodynamic quantity 390 (Simsek and Beker 2014).

$$
\frac{d\left(\ln C_{e}\right)}{d T}=-\frac{\Delta H_{x}}{R T^{2}}
$$

392 In the present study, the calculations for $\Delta \mathrm{H}_{\mathrm{X}}$ are made at constant surface coverage of Qe $=$ $3930.04,0.06,0.08$ and $0.1 \mathrm{~g} / \mathrm{g}$. The $\ln$ of equilibrium concentration $(\mathrm{Ce})$ at a constant amount of 394 adsorbed dye plotted versus $1 / \mathrm{T}$ is used to determine $\Delta \mathrm{H}_{\mathrm{X}}$ from the slope of the plots. In the case 395 of physical adsorption, $\Delta \mathrm{H}_{\mathrm{X}}$ should be below $80 \mathrm{KJ} / \mathrm{mol}$ while for chemisorptions, the $\Delta \mathrm{H}_{\mathrm{X}}$ 396 values range between 80 and $400 \mathrm{KJ} / \mathrm{mol}$ (Saha and Chowdhury 2011). The calculated values of 397 isosteric heat of adsorption are presented in Table 7. The values between 2.71 and $72.60 \mathrm{KJ} / \mathrm{mol}$ 398 mean physical adsorption of CR onto ERH.

399 Table 7 Isosteric heat of adsorption of Congo red onto ERH

\begin{tabular}{lccccc}
\hline \multirow{2}{*}{ Model } & $\begin{array}{c}\text { Constant } \\
\text { Surface } \\
\text { Coverage } \\
\mathbf{Q}_{\mathbf{e}}(\mathbf{g} / \mathbf{g})\end{array}$ & Parameters & & & \\
& \multirow{2}{*}{0.04} & $\Delta \mathrm{H}_{\mathrm{X}}(\mathrm{KJ} / \mathrm{mol})$ & 21.11 & 16.32 & 1.055 \\
\cline { 3 - 6 } Clausius-Clapeyron & $\mathrm{R}^{2}$ & 0.9976 & 0.6938 & 0.331 \\
\cline { 2 - 6 } & 0.06 & $\Delta \mathrm{H}_{\mathrm{X}}(\mathrm{KJ} / \mathrm{mol})$ & 15.91 & 35.98 & 3.60 \\
& & $\mathrm{R}^{2}$ & 0.8834 & 0.9944 & 0.3526 \\
\hline
\end{tabular}




\begin{tabular}{cccccc}
\hline \multirow{2}{*}{0.08} & $\Delta \mathrm{H}_{\mathrm{X}}(\mathrm{KJ} / \mathrm{mol})$ & 8.11 & 27.96 & 11.49 \\
& $\mathrm{R}^{2}$ & 0.8279 & 0.9868 & 0.8458 \\
\cline { 2 - 5 } & \multirow{2}{*}{0.1} & $\Delta \mathrm{H}_{\mathrm{X}}(\mathrm{KJ} / \mathrm{mol})$ & 8.26 & 25.45 & 22.49 \\
& $\mathrm{R}^{2}$ & 0.931 & 0.9787 & 0.9027 \\
\hline
\end{tabular}

401 Mechanism of adsorption of Congo red onto ERH

402 The results presented above showed physical adsorption of Congo red onto the ERH. Lower

403 values of D-R free energy than $8 \mathrm{KJ} / \mathrm{mol}$, lower energy of activation (Ea) than $40 \mathrm{KJ} / \mathrm{mol}$, and

404 the isosteric heat of adsorption $\left(\Delta \mathrm{H}_{\mathrm{X}}\right)$ below $80 \mathrm{KJ} / \mathrm{mol}$ confirm the physical adsorption of CR

405 onto ERH. Congo red is a direct dye that presents Na-salt of diazo dye containing two amino and

406 two sulfonic groups responsible for the creation of hydrogen bonds and determination of the CR

407 solubility, respectively. Theoretically, the adsorption of the direct dye onto cellulose occurs with

408 physical hydrogen bonds (Broadbend, 2001), which confirms the aforementioned statement.

409 Considering the information mentioned above, the proposed schematic of adsorption of CR onto

410 ERH is presented in Fig. 3. 

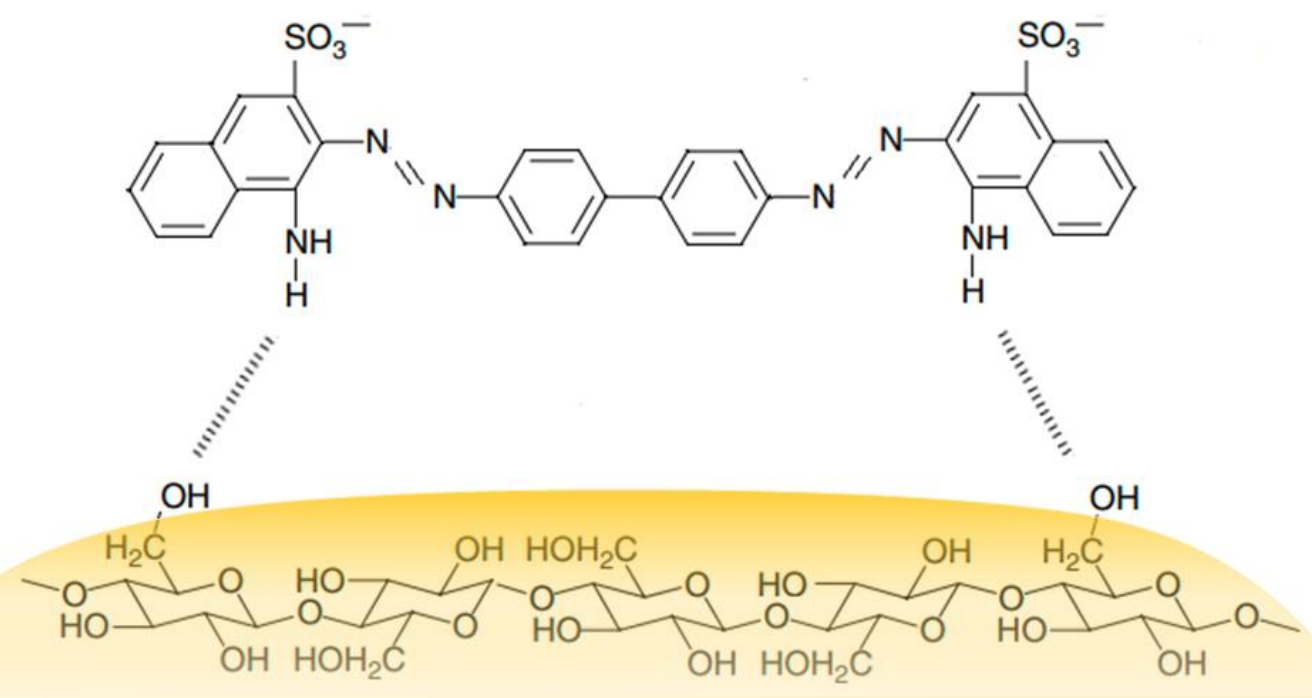

411

412 Fig. 3 Mechanism of adsorption of Congo red onto ERH

\section{4. Conclusion}

415 Equilibrium, kinetic, thermodynamic aspects and mechanism of Congo red adsorption onto rice

416 husk treated with effluent from the cotton scouring are explored. The initial dye concentration,

417 contact time, the mass of rice husk and temperature are crucial in determining the adsorption

418 efficiency of treated rice husk. Adsorption of Congo red follows the Langmuir model, when the

419 mass of rice husk is lower, and the Freundlich model when the dosage is high. The dye removal

420 increases with an increase in adsorbent dose, but the adsorption capacity of the ERH, performed

421 at all temperatures, decreases when the adsorbent mass increases. The maximum adsorption

422 capacity of $149.1 \mathrm{mg}$ CR per gram $\mathrm{ERH}$ was obtained with $10 \mathrm{~g} / \mathrm{L} \mathrm{ERH} \mathrm{at} 70^{\circ} \mathrm{C}$, which is one of 
423 the more remarkable results mentioned in the literature. The activation energy calculated by the

424 Dubinin-Radushkevich isotherm, indicates the physical nature of CR adsorption onto ERH,

425 while the adsorption kinetics follows the pseudo-second-order model. The Energy of activation,

426 standard enthalpy of activation, the entropy of activation and free energy of activation, calculated

427 using the thermodynamic Arrhenius and Eyring equations, have shown the spontaneous

428 endothermic mechanism of adsorption. The isosteric heats of adsorption, estimated by Clausius-

429 Clapeyron equation, with values below $80 \mathrm{KJ} / \mathrm{mol}$, also confirm the physical bonding of the

430 adsorbed CR onto ERH. This modification, performed according to the circular economy

431 concept, acts as a straightforward process for obtaining a cheap adsorbent capable of removing

432 Congo red from an aqueous solution and presents a solid base for creating a continuous column-

433 mode process of rice husk modification and purifying the colored effluent from the textile 434 industry.

436 Notes

437 The authors declare no competing financial interest.

438 Acknowledgments

439 References

440 Abdelwahab O, El Nemr A, El Sikaily A, Khaled A (2005) Use of rice husk for adsorption of 441 direct dyes from aqueous solution: a case study of direct f. scarlet. Egypt J Aquat Res 31:1-11.

442 Aboamera NM, Mohamed A, Salama A, Osman TA, Khattab A (2018) An effective removal of 443 organic dyes using surface functionalized cellulose acetate/graphene oxide composite nanofibers. 444 Cellulose 25:4155-4166. https://doi.org/10.1007/s10570-018-1870-8 
Abu Elella MH, ElHafeez EA, Goda ES, Lee S, Yoon KR (2019) Smart bactericidal filter containing biodegradable polymers for crystal violet dye adsorption. Cellulose 26:9179-9206. https://doi.org/10.1007/s10570-019-02698-1

Acemioğlu B (2004) Adsorption of Congo red from aqueous solution onto calcium-rich fly ash. J Colloid Interface Sci 274:371-379. https://doi.org/10.1016/j.jcis.2004.03.019

Alam MM, Hossain MA, Hossain MD, Johir MAH, Hossen J, Rahman MS, Zhou JL, Hasan ATMK, Karmakar AK, Ahmed MB (2020) The potential of rice husk-derived activated carbon: From synthesis to application. Processes 8, 203. https://doi.org/10.3390/pr8020203

Alaton IA, Teksoy S (2007) Acid dyebath effluent pretreatment using Fenton's reagent: Process optimization, reaction kinetics and effects on acute toxicity. Dyes Pigm 73:31-39. https://doi.org/10.1016/j.dyepig.2005.09.027

Batmaz R, Mohammed N, Zaman M, Minhas G, Berry RM, Tam KC (2014) Cellulose nanocrystals as promising adsorbents for the removal of cationic dyes. Cellulose 21:1655-1665. https://doi.org/10.1007/s10570-014-0168-8

Blackburn RS (2004) Natural polysaccharides and their interactions with dye molecules: applications in effluent treatment. Environ Sci Technol 38:4905-4909. https://doi.org/10.1021/es049972n

Broadbend AD (2001). Basic principles of textile coloration, Society of Dyers and Colorists, Bradford, West Yorkshire, England.

Brown MA, De Vito SC (1993) Predicting azo dye toxicity. Crit Rev Environ Sci Technol 23:249-324. https://doi.org/10.1080/10643389309388453

Chakraborty S, Chowdhury S, Saha PD (2011) Adsorption of Crystal Violet from aqueous solution onto NaOH-modified rice husk. Carbohydr Polym 86:1533-1541.

https://doi.org/10.1016/j.carbpol.2011.06.058

Chen X (2015) Modeling of experimental adsorption isotherm data. Information 6:14-22. https://doi.org/10.3390/info6010014

Ching TW, Haritos V, Tanksale A (2018) Ultrasound-assisted conversion of cellulose into hydrogel and functional carbon material. Cellulose 25:2629-2645.

https://doi.org/10.1007/s10570-018-1746-y

Chong KY, Chia CH, Zakaria S, Sajab MS, Chook SW, Khiew PS (2015) $\mathrm{CaCO}_{3}$-decorated cellulose aerogel for removal of Congo Red from aqueous solution. Cellulose 22:2683-2691. https://doi.org/10.1007/s10570-015-0675-2 
477 Chou KS, Tsai JC, Lo CT (2001) The adsorption of Congo red and vaccum pump oil by rice hull 478 ash. Bioresour Technol 78:217-219. https://doi.org/10.1016/S0960-8524(00)00116-4

479 Chowdhury S, Mishra R, Saha P, Kushwaha P (2011) Adsorption thermodynamics, kinetics and 480 isosteric heat of adsorption of malachite green onto chemically modified rice husk. Desalination 481 265:159-168. https://doi.org/10.1016/j.desal.2010.07.047

482 Chowdhury S, Mishra R, Kushwaha P, Saha P (2012) Removal of safranin from aqueous 483 solutions by $\mathrm{NaOH}$-treated rice husk: Thermodynamics, kinetics and isosteric heat of adsorption.

484 Asia-Pac J Chem Eng 7:236-249. https://doi.org/10.1002/apj.525

485 Chowdhury S, Mishra R, Kushwaha P, Saha P (2010) Sea shell powder as a new adsorbent to 486 remove Basic Green 4 (Malachite Green) from aqueous solutions: Equilibrium, kinetic and 487 488 thermodynamic studies. Chem Eng Sci 164:168-177. https://doi.org/10.1016/j.cej.2010.08.050

Ciardelli G, Capannelli G, Bottino A (2001) Ozone treatment of textile wastewater for reuse. Water Sci Technol 44:61-67. https://doi.org/10.2166/wst.2001.0252

491 Costa Junior IL, Finger L, Quitaiski PP, Neitzke SM, Besen JV, Correa MK, Mees JBD (2018)

492 Biosorption of $5 \mathrm{G}$ blue reactive dye using waste rice husk. Eclet Quim 43:45-58.

493 https://doi.org/10.26850/1678-4618eqj.v43.3.2018.p45-58

494 Dabrowski A (2001). Adsorption -from theory to practice, Adv Colloid Interface Sci 93:135-224. 495 https://doi.org/10.1016/S0001-8686(00)00082-8

496

497

498

499

500

501

502

503

504

505 506

507

508
Dawood S, Sen TK (2012) Removal of anionic dye Congo red from aqueous solution by raw pine and acid-treated pine cone powder as adsorbent: Equilibrium, thermodynamic, kinetics, mechanism and process design. Water Res 46:1933-1946.

https://doi.org/10.1016/j.watres.2012.01.009

Easton JR (1995) Colour in Dyehouse Effluent. In P. Copper (Ed.), Society of Dyers and Colourists: Bradford, England.

El Haddad M (2016) Removal of Basic Fuchsin dye from water using mussel shell biomass waste as an adsorbent: Equilibrium, kinetics, and thermodynamics. J Taibah Univ Sci 10:664674. https://doi.org/10.1016/j.jtusci.2015.08.007

Foo KY, Hameed BH (2010) An overview of dye removal via activated carbon adsorption process. Desalination Water Treat 19:255-274. https://doi.org/10.5004/dwt.2010.1214

$\mathrm{Fu}$ Y, Viraraghavan T (2002) Removal of Congo red from an aqueous solution by fungus Aspergillus niger. Adv Environ Re 7:239- 247. https://doi.org/10.1016/S1093-0191(01)00123-X 
Gedam VV, Raut P, Chahande A. Pathak P (2019) Kinetic, thermodynamics and equilibrium studies on the removal of Congo red dye using activated teak leaf powder. Appl Water Sci 9:55. https://doi.org/10.1007/s13201-019-0933-9

Gorgieva S, Vogrincic R, Kokol V (2019) The effect of membrane structure prepared from carboxymethyl cellulose and cellulose nanofibrils for cationic dye removal. J Polym Environ 27:318-332. https://doi.org/10.1007/s10924-018-1341-1

Gupta VK, Carrot PJM, Ribeiro Carrott MML, Suhas (2009) Low-cost adsorbents: Growing approach to wastewater treatment review. Crit Rev Environ Sci Technol, 39:783-842. https://doi.org/10.1080/10643380801977610

Halysh V, Sevastyanova O, Pikus S, Dobele G, Pasalskiy B, Gun'ko VM, Kartel M (2020) Sugarcane bagasse and straw as low-cost lignocellulosic sorbents for the removal of dyes and metal ions from water. Cellulose 27:8181-8197. https://doi.org/10.1007/s10570-02003339-8

Han R, Ding D, Xu Y, Zou W, Wang Y, Li Y, Zou L (2008) Use of rice husk for the adsorption of Congo red from aqueous solution in column mode. Bioresour Technol 99:2938-2946. https://doi.org/10.1016/j.biortech.2007.06.027

Ivanovska A, Asanovic K, Jankoska M, Mihajlovski K, Pavun L, Kostic M (2020)

Multifunctional jute fabrics obtained by different chemical modifications. Cellulose 27:84858502. https://doi.org/10.1007/s10570-020-03360-x

Jain R, Mathur M, Sikarwar S, Mittal A (2007) Removal of the hazardous dye Rhodamine B through photocatalytic and adsorption treatments. J Environ Manage 85:956-964. https://doi.org/10.1016/j.jenvman.2006.11.002

Kumari R, Mohanta J, Dey B, Dey S (2019) Eucalyptus leaf powder as an efficient scavenger for Congo red from water: Comprehensive batch and column investigation. Sep Sci Technol 55:3047-3059. https://doi.org/10.1080/01496395.2019.1670208

Lakshmi UR, Srivastva VC, Mall ID, Lataye DH (2009) Rice husk ash as an effective adsorbent: Evaluation of adsorptive characteristics for indigo Carmine dye. J Environ Manage 90:710-720. https://doi.org/10.1016/j.jenvman.2008.01.002

Lazic BD, Pejic BM, Kramar AD, Vukcevic MM, Mihajlovski KR, Rusmirovic JD, Kostic MM (2018) Influence of hemicelluloses and lignin content on structure and sorption properties of flax fibers (Linum usitatissimum L.). Cellulose 25:697-709. https://doi.org/10.1007/s10570-017$1575-4$

Lian L, Guo L, Guo C (2009) Adsorption of Congo red from aqueous solutions onto Cabentonite. J Hazard Mater 161:126-131. https://doi.org/10.1016/j.jhazmat.2008.03.063 
543 Males L, Fakin D, Bracic M, Gorgieva S (2020) Efficiency of differently processed membranes

544 based on cellulose as cationic dye adsorbents. Nanomaterials 10:1-18.

545 Mane VS, Mall ID, Srivastava VC (2007) Kinetic and equilibrium isotherm studies for 546 adsorptive removal brilliant green dye from aqueous solution by rice husk ash. J Environ

547 Manage 84:90-400. https://doi.org/10.1016/j.jenvman.2006.06.024

548 Mladenovic N, Makreski P, Tarbuk A, Grgic K, Boev B, Mirakovski D, Toshikj E, Dimova V, 549 Dimitrovksi D, Jordanov I (2020) Improved dye removal ability of modified rice husk with 550 effluent from alkaline scouring based on the circular economy concept. Processes 8:653. 551 https://doi.org/10.3390/pr8060653

552 Mohamed RR, Abu Elella MH, Sabaa MW, Saad GR (2018) Synthesis of an efficient adsorbent 553 hydrogel based on biodegradable polymers for removing crystal violet dye from aqueous 554 solution. Cellulose 25:6513-6529. https://doi.org/10.1007/s10570-018-2014-x

555 Namasivayam C, Kavitha D (2002) Removal of Congo red from water by adsorption onto 556 activated carbon prepared from coir pith, an agricultural solid waste. Dyes Pigm 54:47-58. 557 https://doi.org/10.1016/S0143-7208(02)00025-6

558 Namasivayam C, Muniasamy N, Gayatri K, Rani M, Ranganathan K (1996) Removal of dyes 559 from aqueous solutions by cellulosic waste orange peel. Bioresour Technol 57:37-43.

560 https://doi.org/10.1016/0960-8524(96)00044-2

561 Ndazi BS, Karlsson S, Tesha JV, Nyahumwa CW (2007) Chemical and physical modifications

562 of rice husks for use as composite panels. Compos Part A Appl Sci Manuf 38:925-935.

563 https://doi.org/10.1016/j.compositesa.2006.07.004

564 Omidi S, Kakanejadifard A (2018) Eco-friendly synthesis of graphene-chitosan composite 565 hydrogel as efficient adsorbent for Congo red. RSC Adv. 8:12179.

566 https://doi.org/10.1039/c8ra00510a

567 Ong ST, Lee CK, Zainal Z (2007) Removal of basic and reactive dyes using Ethylenediamine 568 modified rice hull. Bioresour Technol 98:2792-2799.

569 https://doi.org/10.1016/j.biortech.2006.05.011

570 Panda GC, Das SK, Guha AK (2008) Jute stick powder as a potential biomass for the removal of 571 Congo red and rhodamine B from their aqueous solution. J Hazard Mater 164:374- 379.

572 https://doi.org/10.1016/j.jhazmat.2008.08.015

573 Parvin S, Biswas BK, Rahman MA, Rahman MH, Anik MS, Uddin MR (2019) Study on

574 adsorption of Congo red onto chemically modified egg shell membrane. Chemosphere 575 236:124326. https://doi.org/10.1016/j.chemosphere.2019.07.057 
Perez-Ameneiro M, Vecino X, Barbosa-Pereira L, Cruz JM, Moldes AB (2014) Removal of pigments from aqueous solution by a calcium alginate-grape marc biopolymer: A kinetic study. Carbohydr Polym 101:954-960. https://doi.org/10.1016/j.carbpol.2013.09.091

Qiao L, Wang S, Wang T, Yu S, Guo S, Du K (2021) High-strength and low-swelling chitosan/cellulose microspheres as a high-efficiency adsorbent for dye removal. Cellulose 28:9323-9333. https://doi.org/10.1007/s10570-021-04111-2

Quansah JO, Hlaing T, Lyonga FN, Kyi PP, Hong S.-H, Lee C.-G, Park S.-J (2020) Nascent Rice Husk as an Adsorbent for Removing Cationic Dyes from Textile Wastewater. Appl Sci 10:3437. https://doi.org/10.3390/app10103437

Rasool K, Lee DS (2015) Characteristics, kinetics and thermodynamics of Congo red biosorption by activated sulfidogenic sludge from an aqueous solution. Int J Environ Sci Technol 12:571580. https://doi.org/10.1007/s13762-013-0462-2

Safa Y, Bhatti HN (2011) Adsorptive removal of direct dyes by low cost rice husk: Effect of treatments and modifications. Afr J Biotechnol 10:3128-3142. https://doi.org/10.5897/AJB10.1302

Sanghi R, Verma P (2013) Decolorisation of aqueous dye solutions by low-cost adsorbents: A review. Color Technol 129:85-108. https://doi.org/10.1111/cote.12019

Saha P, Chowdhury S (2011) Insight Into Adsorption Thermodynamics. In M. Tadashi (Ed.), Thermodynamics, 349-364. IntechOpen Limited, London, UK. https://doi.org/10.5772/13474

Shamsollahi Z, Partovinia A (2019) Recent advances on pollutants removal by rice husk as a biobased adsorbent: A critical review. J Environ Manage 246:314-323. https://doi.org/10.1016/j.jenvman.2019.05.145

Shao X, Wang J, Liu Z, Hu N, Liu M, Duan C, Zhang R, Quan C (2021) Cellulose based cationexchange fiber as filtration material for the rapid removal of methylene blue from wastewater. Cellulose 28:9355-9367. https://doi.org/10.1007/s10570-021-04103-2

Sharma P, Kaur H, Sharma M, Sahore, V (2011) A review on applicability of naturally available adsorbents for the removal of hazardous dyes from aqueous waste. Environ Monit Assess 183:151-195. https://doi.org/10.1007/s10661-011-1914-0

Simsek EB, Beker U (2014) Equilibrium arsenic adsorption onto metallic oxides: Isotherm models, error analysis and removal mechanism. Korean J Chem Eng 31:2057-2069. https://doi.org/10.1007/s11814-014-0176-2

Tarbuk A, Grgic K, Toshikj E, Domovic D, Dimitrovski D, Dimova V, Jordanov I (2020) Monitoring of cellulose oxidation level by electrokinetic phenomena and numeric prediction model. Cellulose 27:3107-3119. https://doi.org/10.1007/s10570-020-03028-6 
610 Toshikj E, Tarbuk A, Grgic K, Mangovska B, Jordanov I (2019) Influence of different oxidizing 611 systems on cellulose oxidation level: introduced groups versus degradation model. Cellulose

612 26:777-794. https://doi.org/10.1007/s10570-018-2133-4

613 Toshikj E, Jordanov I, Dimova V, Mangovska B (2017) Influence of Various Pre-Treatment 614 Processes on Selective Oxidation of Cotton Yarns. AATCC J Res 4:22-28.

615 https://doi.org/10.14504/ajr.4.4.4

616 Toshikj E, Jordanov I, Dimova V, Mangovska B (2016) The influence of non-selective oxidation 617 on differently pre-treated cotton yarns properties. Medziagotyra 22:429-434

618 https://doi.org/10.5755/j01.ms.22.3.12110

619 Vadivelan V, Vasanth Kumar K (2005) Equilibrium, kinetics, mechanism, and process design for 620 the sorption of methylene blue onto rice husk. J Colloid Interface Sci 286:90-100.

621 https://doi.org/10.1016/j.jcis.2005.01.007

622 Vimonses V, Lei S, Jin B, Chow CWK, Saint C (2009) Kinetic study and equilibrium isotherm 623 analysis of Congo red adsorption by clay materials. Chem Eng J 148:354-364.

624 https://doi.org/10.1016/j.cej.2008.09.009

625 Yang K, Li Y, Zheng H, Luan X, Li H, Wang Y, Du Q, Sui K, Li H, \& Xia Y (2019) Adsorption 626 of Congo red with hydrothermal treated shiitake mushroom. Mater Res Express 7:015103.

627 https://doi.org/10.1088/2053-1591/ab5ff3

628 Zhu CS, Wang LP, Chen WB (2009) Removal of Cu(II) from aqueous solution by agricultural 629 by-product: peanut hull. J Hazard Mater 168:739-746.

630 https://doi.org/10.1016/j.jhazmat.2009.02.085

631 Zou W, Li K, Bai H, Shi X (2011) Enhanced cationic dyes removal from aqueous solution by 632 oxalic acid modified rice husk. J Chem Eng Data 56:1882-1891.

633 https://doi.org/10.1021/je100893h 


\section{Supplementary Files}

This is a list of supplementary files associated with this preprint. Click to download.

- SupplementaryfileCellulose.docx 